\title{
Krill-copepod interactions at South Georgia, Antarctica, II. Euphausia superba as a major control on copepod abundance
}

\author{
A. Atkinson*, P. Ward, A. Hill, A. S. Brierley, G. C. Cripps \\ British Antarctic Survey, Natural Environment Research Council, High Cross, Madingley Road, Cambridge CB3 0ET, \\ United Kingdom
}

\begin{abstract}
Euphausia superba (hereafter 'krill') and copepods are major zooplankton taxa in the Southern Ocean, but there is little information on how they interact. This paper investigates their coincidence across a wide range of temporal and spatial scales to examine whether copepod distribution is related to that of krill. During 2 summers of high krill abundance near South Georgia (1996 and 1997) copepod abundance was $<40 \%$ of that during an abnormally low krill year (1994). No such depletion was found north of the Polar Front, where krill were rare. Analysis of 2 mesoscale data sets showed that krill, rather than food or environmental factors, were most strongly implicated in copepod distribution. An area of persistently high krill abundance just north of South Georgia was characterised by exceptionally few copepods. Fine-scale relationships between patches of krill and copepods were studied with a Longhurst Hardy Plankton Recorder. Within krill swarms copepod abundance was low, but more dispersed krill associated with high concentrations of copepods. Copepods also appeared to live deeper and to make more extensive vertical migrations when krill were present. The inverse relationship between krill and copepod abundances thus occurred repeatedly and across a wide range of scales. The facts that krill swarms are mobile and were unrelated to hydrography further suggest that the inverse relationship was caused by krill. This could arise from competitive exclusion, direct predation or both. Evidence for competition is that South Georgia copepods rely on high phytoplankton biomass for recruitment and krill can remove this. Predation is suggested by the fact that crustaceans were found in krill guts in this region during both summer and winter. During the 1996 summer, experimentally derived predation rates on copepods, combined with krill biomass values, suggested a significant impact on small copepods. Therefore we suggest that copepod numbers can be controlled by a combination of competition and predation by krill.
\end{abstract}

KEY WORDS: Antarctic krill - Euphausia superba · Copepods · South Georgia - Southern Ocean Distribution Population control · Feeding interactions

\section{INTRODUCTION}

Verity \& Smetacek (1996) have argued that zooplankton have been analysed mainly from the perspective of bottom-up controls such as water temperature and food availability, and that top-down controls such as predation are neglected. This approach persists despite demonstrations that important types of behaviour such as diel vertical migration are often modified by predators (e.g. Dawidowicz et al. 1990, Bollens \& Stearns 1992, Frost \& Bollens 1992). In the Southern

•E-mail:a.atkinson@bas.ac.uk
Ocean, zooplankton distributions have been viewed almost exclusively in terms of hydrography and phytoplankton (e.g. Mackintosh 1934, Marin 1987, Piatkowski 1989, Atkinson et al. 1990, Siegel \& Piatkowski 1990, Bathmann et al. 1993, Hosie \& Cochran 1994). This has been due to by lack of information on the competitive and predatory interactions between key groups (e.g. Kawamura 1986, Vuorinen et al. 1997).

In the Southern Ocean food web, the 3 major taxa are euphausiids (particularly Euphausia superba), copepods and salps, their relative importance varying regionally. An interaction between E. superba (hereafter 'krill') and salps has been suggested (Huntley et 
al. 1989, Loeb et al. 1997) but how (or whether) copepods interact with either group is largely unknown. The trophic relationship between krill and copepods is controversial. During blooms, phytoplankton may be the main food of both krill (Quetin \& Ross 1991, Hopkins et al. 1993a, Pond et al. 1993) and many epipelagic copepods (Schnack 1985, Hopkins et al. 1993a, Atkinson 1995), so therefore they presumably compete for food. During the long periods with less phytoplankton, there is growing evidence that krill can feed omrivorously (Hopkins \& Torres 1989, Froneman et al. 1996, Pakhomov et al. 1997a, Perissinotto et al. 1997) and can eat copepods (Price et al. 1988, Nordhausen \& Huntley 1992, Atkinson \& Snÿder 1997). However, opinion is divided on whether copepods are a significant food source for krill (compare Quetin \& Ross 1991 with Huntley et al. 1994, Atkinson \& Snÿder 1997, Perissinotto et al. 1997).

Whether krill compete with copepods, prey on them, or both, they are likely to be detrimental to copepod livelihood. However, these 2 groups are often examined both separately and in terms of bottom-up controls, so there is little evidence of whether krill influence copepod abundance. When analysing such distribution data it is also difficult to determine causation from correlation (Rose \& Leggett 1990). For example, many of the most abundant copepods (e.g. Oithona similis) are commonest in northern Antarctic latitudes (Atkinson 1998), whereas krill are more abundant further south. Thus, a negative correlation between them at a large scale could simply reflect biogeographic affinities rather than a direct interaction. However, krill are mobile and patchily distributed, and in this study we found that, at fine and mesoscales, their distribution was unrelated to water masses. This allowed us to disentangle the possible effects of krill and environment on copepod abundance. Our approach is thus to develop the analysis of copepod distributions beyond the search for bottom-up controls.

South Georgia is a good study site for such an approach. It supports a very high biomass of both copepods and krill (Everson \& Goss 1991, Ward et al. 1995. Atkinson et al. 1996, Brierley et al. 1997, Pakhomov et al. 1997b), but once or twice a decade krill are much reduced, causing breeding failure of their predators (Boyd et al. 1995, Croxall \& Rothery 1995). The large local, regional and interannual variations are therefore a natural experiment in krill-copepod interactions. South Georgia has also been well studied, so there is a good background knowledge of the bottomup controls on which to base this analysis. We have compiled a variety of surveys from different years to study krill-copepod interactions across as wide a range of scales as possible. These surveys encompass finescale vertical and horizontal, through mesoscale to large-scale regional and interannual variations.

\section{METHODS}

Data sets. We compiled all our South Georgia data sets in which krill and copepods were quantified concurrently. These encompass a wide range of scales and are summarised in Table 1 . The data sets are numbered to ease cross referencing between 'Methods' and 'Results'. Most of the data are unpublished, but

Table 1. Summary of sampling details for the South. Georgia data sets. Data sets are numbered in accordance with the cross referencing between 'Methods' and 'Results' sections. RMT 1+8: Multiple Rectangular. Midwater Traw1; LHPR: Longhurst Hardy Plankton Recorder

\begin{tabular}{|c|c|c|}
\hline Data set & Nets used & $\begin{array}{l}\text { Comments, and references if previous } \\
\text { interpretations have been made }\end{array}$ \\
\hline (1) Interannual variability, 1994-1996-1997 & $\begin{array}{l}\text { Mainly } \\
\text { bongo } \\
\text { nets }\end{array}$ & $\begin{array}{l}\text { Comparison over a wide area from north of the } \\
\text { Polar Front to the South Georgia shelf. } 1994 \text { data } \\
\text { have been reported by Ward et al. (1996) }\end{array}$ \\
\hline (2) Mesoscale variability, 1996 and 1997 & Bongo nets & $\begin{array}{l}1996 \text { and } 1997 \text { data used in (1), divided on a } \\
\text { regional basis }\end{array}$ \\
\hline (3) Mesoscale survey, 1981 & RMT $1+8$ & $\begin{array}{l}\text { Grid of } 57 \text { stations centered on South Georgia } \\
\text { (Atkinson \& Peck 1990, Atkinson et al. 1990) }\end{array}$ \\
\hline (4) Fine-scale horizontal distribution, 1996 & LHPR & $\begin{array}{l}5 \text { horizontal tows with sampling interval } \\
\text { of } \sim 40 \text { to } 50 \mathrm{~m}\end{array}$ \\
\hline (5) Fine-scale vertical distribution, 1994-1996 comparison & LHPR & $\begin{array}{l}\text { Comparison of diel migration at shelf and oceanic } \\
\text { monitoring sites ( } 7 \text { profiles in } 1994 \text { [Atkinson et al. } \\
\text { 1996] and } 4 \text { in 1996) }\end{array}$ \\
\hline (6) Fine-scale vertical distribution, 1990 diel series & LHPR & $\begin{array}{l}17 \text { profiles at shelf monitoring site; } 2 \text { made in a } \\
\text { krill aggregation (Atkinson et al. 1992) }\end{array}$ \\
\hline
\end{tabular}


Table 2. Sampling details of surveys used to study interannual, 1994-1996-1997, and mesoscale, 1996 and 1997, variability of zooplankton distribution. 'Shelf site' and 'Oceanic site' fixed monitoring sites off the northwest tip of South Georgia at $53^{\circ} 54^{\prime}$ S, $38^{\circ} 39^{\prime} \mathrm{W}$ and $53^{\circ} 03^{\prime} \mathrm{S}, 39^{\circ} 23^{\prime} \mathrm{W}$ respectively. R: ring net; B: bongo net; LHPR: Longhurst Hardy Plankton Recorder. Hauls were to $200 \mathrm{~m}$ with $200 \mu \mathrm{m}$ mesh nets unless indicated otherwise

\begin{tabular}{|c|c|c|c|c|}
\hline Date & Net type & No. of hauls & Position & Notes/references \\
\hline \multicolumn{5}{|l|}{ Jan-Feb 1994} \\
\hline $3-5 \mathrm{Jan}$ & $\mathrm{R}$ & 9 & $\begin{array}{l}\text { Transect between Subantarctic Front } \\
\text { and South Georgia shelf }\end{array}$ & $\begin{array}{l}500 \mu \mathrm{m} \text { nets used for } 5 \text { of the } \\
\text { hauls (Ward et al. 1996) }\end{array}$ \\
\hline $17-18 \mathrm{Jan}$ & L.HPR & 7 & Shelf site & $\begin{array}{l}\text { Oblique tows on a diel cycle } \\
\text { (Atkinson et al. 1996) }\end{array}$ \\
\hline $17 \mathrm{Jan}$ & $\mathrm{R}$ & 3 & Shelf site & \\
\hline $2-4 \mathrm{Feb}$ & $\mathrm{R}$ & 14 & $\begin{array}{l}\text { Transect between Subantarctic Front and } \\
\text { South Georgia shelf }\end{array}$ & Ward et al. (1996) \\
\hline \multicolumn{5}{|l|}{ Jan 1996} \\
\hline $6-10 \mathrm{Jan}$ & $\mathrm{B}$ & 17 & $\begin{array}{l}\text { Transect between Subantarctic Front and } \\
\text { South Georgia shelf }\end{array}$ & \\
\hline $12-21 \mathrm{Jan}$ & B & 11 & Shelf and oceanic grids north of South Georgia & \\
\hline $22-23 \mathrm{Jan}$ & LHPR & 2 & Shelf site & $\begin{array}{l}\text { Day and night oblique profiles } \\
\text { to } 150 \mathrm{~m}\end{array}$ \\
\hline $28 \mathrm{Jan}$ & LHPR & 2 & Oceanic site & Day and night oblique profiles \\
\hline \multicolumn{5}{|l|}{ Dec 1996-Jan 1997} \\
\hline $15-20 \mathrm{Dec}$ & $\mathrm{B}$ & 16 & $\begin{array}{l}\text { Transect between Subantarctic Front and } \\
\text { South Georgia shelf }\end{array}$ & \\
\hline 23 Dec-1 Jan & $\mathrm{B}$ & 15 & Shelf and oceanic grids north of South Georgia & \\
\hline
\end{tabular}

several data sets have been re-analysed. The older data were collected with the main intention of relating zooplankton distribution to the physical environment and available food. Where these interpretations have already been published they are listed in Table 1.

(1 and 2) Interannual, 1994-1996-1997, and mesoscale, 1996 and 1997 variability. Similar net sampling sites were occupied during the summers of 1994, 1996 and 1997 (Table 2, see Fig 1), which facilitates their comparison. Comparable stations were, firstly, those on a transect running northwestwards from the northern South Georgia shelf to the Subantarctic Front. This transect was worked twice in 1994, in January and February, once in January 1996 and once in December 1996 -January 1997. Secondly, a pair of sites was occupied for more detailed studies. These are referred to hereafter as the 'shelf site' and the 'oceanic site' (Table 2), and lie at the southern end of the transect. The 1996 and 1996-1997 surveys included additional monitoring grids in shelf and oceanic water to the north and northeast of the island (Table 2, Fig. 1). Nets used in 1994 were a $75 \mathrm{~cm}$ diameter ring net at the transect stations and a Longhurst Hardy Plankton Recorder (LHPR; see Longhurst \& Williams 1976) which was towed on 'double oblique' trajectories during a diel cycle for a picture of vertical migration at the shelf site. In 1996 the LHPR was used for a similar purpose at the shelf and oceanic sites; at all other sites in 1996 and 1997 the vertical ring net was substituted with a $61 \mathrm{~cm}$ diameter bongo net pair. Nets with $200 \mu \mathrm{m}$ mesh were used for all hauls except at the most southerly 5 stations on the January 1994 transect, where clogging from a diatom bloom necessitated the use of a $500 \mu \mathrm{m}$ mesh. All net hauls integrated the top $200 \mathrm{~m}$ layer, with the exception of the LHPR over the shelf during 1996 (Table 2), where a $150 \mathrm{~m}$ bottom depth was used to avoid risking contact of the sampler with the seabed. The samples were all preserved in $4 \%$ formaldehyde-filtered seawater.

Acoustic krill biomass estimates were made along the transects using a dual frequency EK 500 echosounder and echointegrator operating at 38 and $120 \mathrm{kHz}$. Only targets which had krill's characteristic mean volume backscattering range (Madureira et al. $1993 a, b)$ were included in the krill biomass estimate. Acoustic records obtained either during the hours of darkness, when krill may have been above the hullmounted transducer, or during periods of rough weather were excluded because of their unreliability. Further details of acoustic surveys are given in Brierley \& Watkins (1996) and Brierley et al. (1997, 1998).

(3) Mesoscale survey, 1981. This semi-synoptic survey was in early austral summer (NovemberDecember 1981) and covered a rectangular grid of 57 stations spaced at $50 \mathrm{~km}$ intervals. A full description of net sampling, sample analysis and data analysis is in Atkinson et al. (1990) and is only summarised here. The data re-analysed here are from oblique down- 
Table 3. Details of horizontal tows with the LHPR during 1996 used to study the fine-scale horizontal distribution of zooplankton

\begin{tabular}{|lccc|}
\hline $\begin{array}{l}\text { LHPR } \\
\text { haul }\end{array}$ & Date & Local time (GMT $-3 \mathrm{~h})$ & Position \\
\hline 1 & 23-24 Jan & $23: 25-00: 04 \mathrm{~h}$ (night) & Shelf site \\
2 & 24 Jan & $05: 20-06: 09 \mathrm{~h}$ (day) & Shelf site \\
3 & 24 Jan & $01: 06-01: 51 \mathrm{~h}$ (night) & Shelf site \\
4 & 23 Feb & $02: 26-03: 06 \mathrm{~h}$ (night) & Shelf site \\
5 & 29 Jan & $09: 01-10: 21 \mathrm{~h}$ (day) & Oceanic site \\
\hline
\end{tabular}

wards tows with the Multiple Rectangular Midwater Trawl (RMT 1+8) described by Roe \& Shale (1979). The cod end mesh size of the RMT 8 was $\sim 4.5 \mathrm{~mm}$ and the RMT 1 was of $330 \mu \mathrm{m}$. The hauls were integrated over the top $250 \mathrm{~m}$ layer, except for those at several of the inner shelf stations, where bottom topography dictated shallower tows. Haul duration was $\sim 30 \mathrm{~min}$, during which the RMT 1 swept 1000 to $1500 \mathrm{~m}^{3}$ of water

Acoustic data were also collected along the transects between stations using an echosounder operating at $120 \mathrm{kHz}$. Further details of acoustic krill biomass estimates are provided by Murphy et al. (1991).

(4) Fine-scale horizontal distribution, 1996. To investigate the co-occurrence of aggregations of krill and copepods, 5 LHPR tows, each 2 to $3 \mathrm{~km}$ long, were made at the shelf and oceanic sites in January-February 1996 (Table 3). These were made at $30 \mathrm{~m}$ depth within the upper mixed layer. The LHPR (mesh size $200 \mu \mathrm{m}$ ) was interfaced with a PROPLUS ${ }^{\otimes}$ control system (Spartel Ltd, Plymouth, UK) and a downwire net monitor, which enabled real time control of the net trajectory to maintain constant sampling depth. The sampling interval (i.e. the elapsed time between consecutive advancements of the cod-end spool) was $30 \mathrm{~s}$. Towing speed was maintained at $1.5 \mathrm{~m} \mathrm{~s}^{-1}$, so each sample represented a horizontal distance of 40 to $50 \mathrm{~m}$ and a filtered volume of $-5 \mathrm{~m}^{3}$ A flowmeter inside the $38 \mathrm{~cm}$ diameter mouth of the LHPR enabled calculation of the distance covered and volume filtered for each sample. A software problem during Hauls 1 and 3 meant that there were no flowmeter data, but the similarities in towing speeds to those of the other hauls allowed mean flow values for Hauls 2, 4 and 5 to be applied.

(5) Fine-scale vertical distribution, 1994-1996 comparison. At the shelf and oceanic monitoring sites during 1994 and 1996, LHPR profiles were obtained by oblique downwards and upwards profiles to $200 \mathrm{~m}$ (or, over the shelf, to as near this depth as water depth would allow). During 1994, 7 double oblique hauls were made with a $200 \mu \mathrm{m}$ mesh LHPR over a diel cycle (Table 2). A detailed account of the environment and the vertical distribution of zooplankton is given in
Atkinson et al. (1996). LHPR sampling in 1996 was limited to a downward and upward oblique profile at approximately midday and midnight at both the shelf and oceanic sites (Table 2).

(6) Fine-scale vertical distribution, 1990 diel series. The aim of this analysis was to investigate whether the localised presence of krill swarms had a noticeable effect on the diel vertical migration cycle of copepods. Diel LHPR profiles have been taken near South Georgia during several seasons (see above), but the 1994 season could not be used because krill were rare that season and not encountered during the diel series. The 1996 diel series could not be used because low numbers of krill were caught throughout both the midday and midnight profiles. During the 1990 diel series, either low numbers of or no krill were caught on all but 2 of the profiles. A detailed account of the diel vertical migration and feeding of copepods in relation to food and physical environment is reported in Atkinson et al. (1992). However, during the ascent profile on which many krill were caught, the vertical distribution pattern of the large copepods was clearly anomalous (up to $100 \mathrm{~m}$ deeper than in all the other profiles). This profile was considered an outlier and excluded from the original analysis of diel vertical migration in relation to the environment (Atkinson et al. 1992). It is included here to study the relation this distribution pattern has with krill distribution.

Sample analysis. With the exception of the 1981 RMT 8 catches, which were analysed on board, all samples were preserved in formaldehyde and analysed under a binocular microscope in the UK. A Folsom plankton splitter was used where necessary to obtain countable aliquots. Although all zooplankton taxa were enumerated, this study is concerned mainly with copepods and krill, which heavily dominate both abundance and biomass in this area (Ward et al. 1995, Atkinson et al. 1996, Brierley et al. 1997, Pakhomov et al. 1997b). For most hauls, identification was to genus or to species, with further enumeration of the copepodite stages of the 4 large biomass dominant copepods, Calanoides acutus, Calanus simillimus, Calanus propinquus and Rhincalanus gigas. A large number (452) of L.HPR samples were analysed from 1996, so the copepods were enumerated in 4 simple groups, namely 'Oithona spp.' (all copepodite stages), 'small calanoid copepods', 'large calanoid copepods' and lastly ' $R$. gigas stages $C V$ plus CVI'. The 'small calanoid' group comprised all copepodite stages of the families Pseudocalaniidae, Clausocalaniidae and Metridiidae. The 'large calanoid' group comprised all copepodids of species with adults of prosome length $>3 \mathrm{~mm}$ (i.e. mainly $C$. acutus, C. simillimus, $C$. propinquus, Euchaeta antarctica) plus CI-CIV of $R$. gigas. This size-based classification was chosen because 
Atkinson \& Snÿder (1997) used a similar classification to assess the feeding rates of krill on copepods.

Abundance values from the ring net hauls were based on the mouth areas of the nets and the vertical distance of tow, and assumed a $100 \%$ filtering efficiency. This approximation was justified by tests with a flowmeter on subsequent field seasons. The same assumptions were applied for the LHPR, except that distance travelled was calculated from the flowmeter data. Volumes filtered by the RMT nets were calculated from flowmeter data using the equations of Roe et al. (1980) and Pommeranz et al. (1983).

\section{RESULTS}

\section{(1) Interannual variability, 1994-1996-1997}

\section{Environment}

The physical environment during the 1994 and 1996 surveys is described by Trathan et al. (1997) and Trathan et al. (British Antarctic Survey unpubl. data). There were no major differences in the physical environment among the 3 years (M. Brandon, British Antarctic Survey, unpubl. data), but during the 1996-1997 survey there was a large warm water eddy at the northern end of the transect. Also, water temperatures in January 1994 tended to be slightly higher than in January 1996. The Polar Front was situated in approximately the same position on all 3 surveys (Fig. 1). Bottom topography in this region seems to constrain the position of the Polar Front, and shifts of more than $\sim 100 \mathrm{~km}$ from its mean position are rare here (Trathan et al. 1997)

In contrast, the seasons differed greatly in chlorophyll â (chl a) concentrations. During January 1994 there was an extensive bloom of large diatoms (>6 $\mathrm{mg}$ chl $a \mathrm{~m}^{-3}$ ) south of the Polar Front, and chl a concentrations $>4 \mathrm{mg} \mathrm{m}^{-3}$ extended onto the South Georgia shelf (Ward et al. 1996, Whitehouse et al. 1996b). When the transect was repeated in early February, mainly post bloom conditions were encountered. In January 1996 there was no bloom except over parts of the South Georgia shelf, and chl a concentrations averaged $\sim 1 \mathrm{mg} \mathrm{m}^{-3}$ (Priddle et al. 1997). However, in late February near the end of our 1996 field season (after the sampling described in this paper), repeat visits to the South Georgia shelf and oceanic monitoring sites revealed a dense bloom with chl a concentrations similar to those in January 1994. During the December 1996 - January 1997 survey, chl a concentrations only reached bloom levels in the oceanic area to the west of the island (M. J. Whitehouse, British Antarctic Survey, unpubl. data).

\section{Krill}

During surveys over a comparable area (i.e. the northern South Georgia shelf and neighbouring ocean) krill biomass in 1994 was roughly one tenth of the values in 1996 and 1997 (Brierley \& Watkins 1996, Brierley et al. 1997; Fig. 2). In 1996 and 1997 krill were caught in bongo nets as far north as the Polar Front, but in both of these high krill years the main concentrations were detected acoustically over the South Georgia shelf and in the oceanic regions adjacent to South Georgia (A. S. Brierley, British Antarctic Survey, pers. comm.). During all 3 summers krill were mainly in the top $100 \mathrm{~m}$ layer. Fig. 2 compares biomass of krill and copepods in the 3 field seasons, having converted from numerical abundances of copepods (using our own unpublished data) and from acoustically derived krill wet masses using equations in Morris et al. (1988).

\section{Copepods}

The clearest difference among the 3 years was the rarity of copepods south of the Polar Front during the 2 summers of high krill abundance, 1996 and 1997 (Fig. 1, Table 4). There, total copepod abundance in the high krill years was only $38 \%$ of that in the 1994 summer (Table 4). To ease presentation, copepods were grouped into 4 size groups (see 'Methods: Sample analysis'). Most severely depleted was the 'large calanoid' group, with the smallest and largest copepods (respectively 'Oithona spp.' and 'Rhincalanus gigas $\mathrm{CV}$ plus $\mathrm{CVI}$ ') less affected. All 4 members of the 'large calanoid' group were depleted: both characteristic Antarctic species (Calanoides acutus, Calanus propinquus) and warmer water species (Calanus simillimus and Rhincalanus gigas). Mann-Whitney $U$-tests on 1994, 1996 and 1997 median abundances south of the Polar Front (Table 4) demonstrated significant decreases $(p<0.05)$ for all the groups except ' $R$. gigas $C V$ plus CVI'. These significant interannual differences were not recorded to the north of the Polar Front. Fig 2 illustrates the year-to-year shifts in dominance between krill and copepods south of the Polar Front in terms of biomass.

\section{(2) Mesoscale variability, 1996 and 1997 surveys}

The aim of this analysis was to determine whether, during seasons of high krill abundance, mesoscale variations in copepod numbers were related to those in krill numbers. The 1994 survey was not used here because of its more restricted regional coverage and because krill were rare throughout the survey area. 

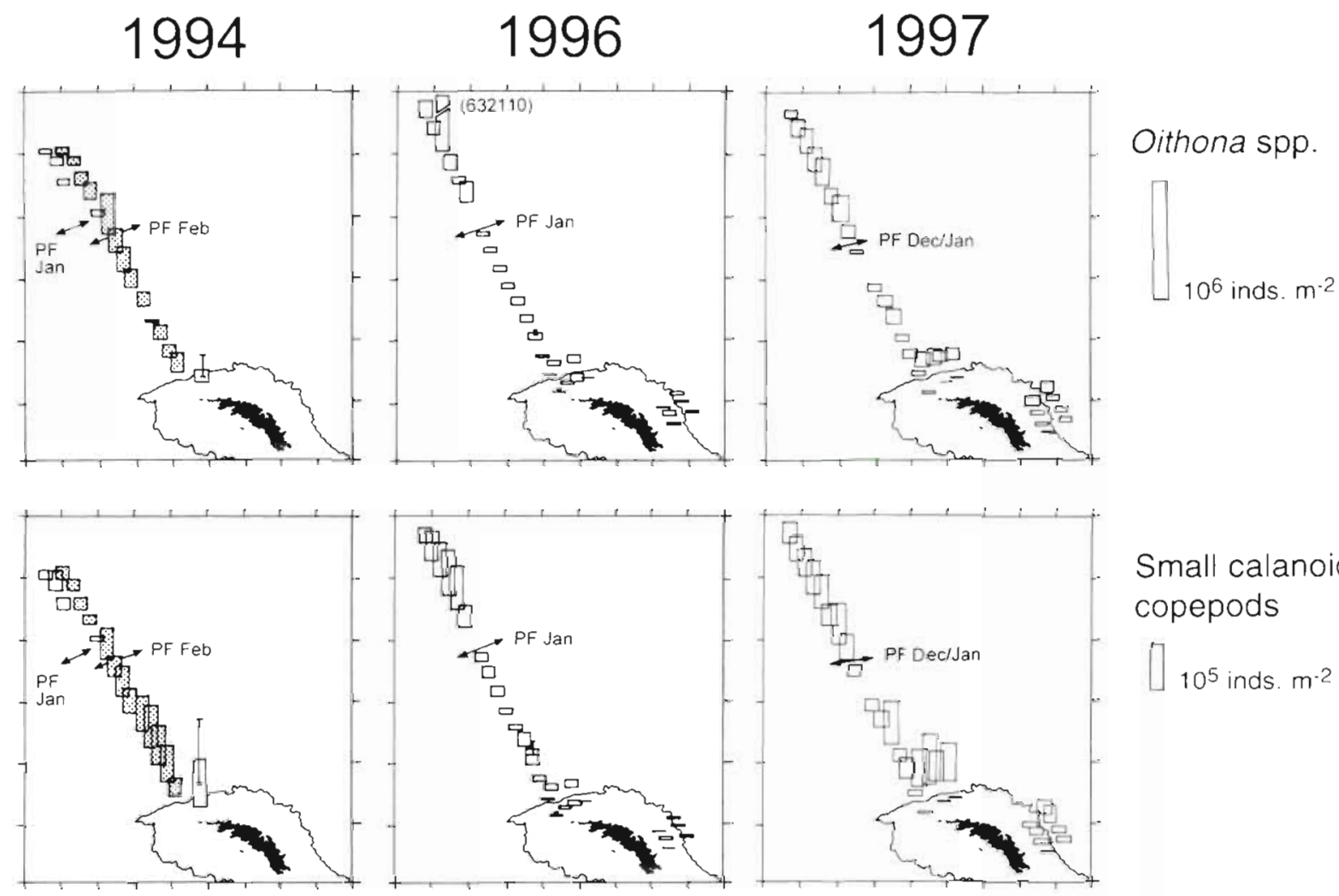

Small calanoid copepods
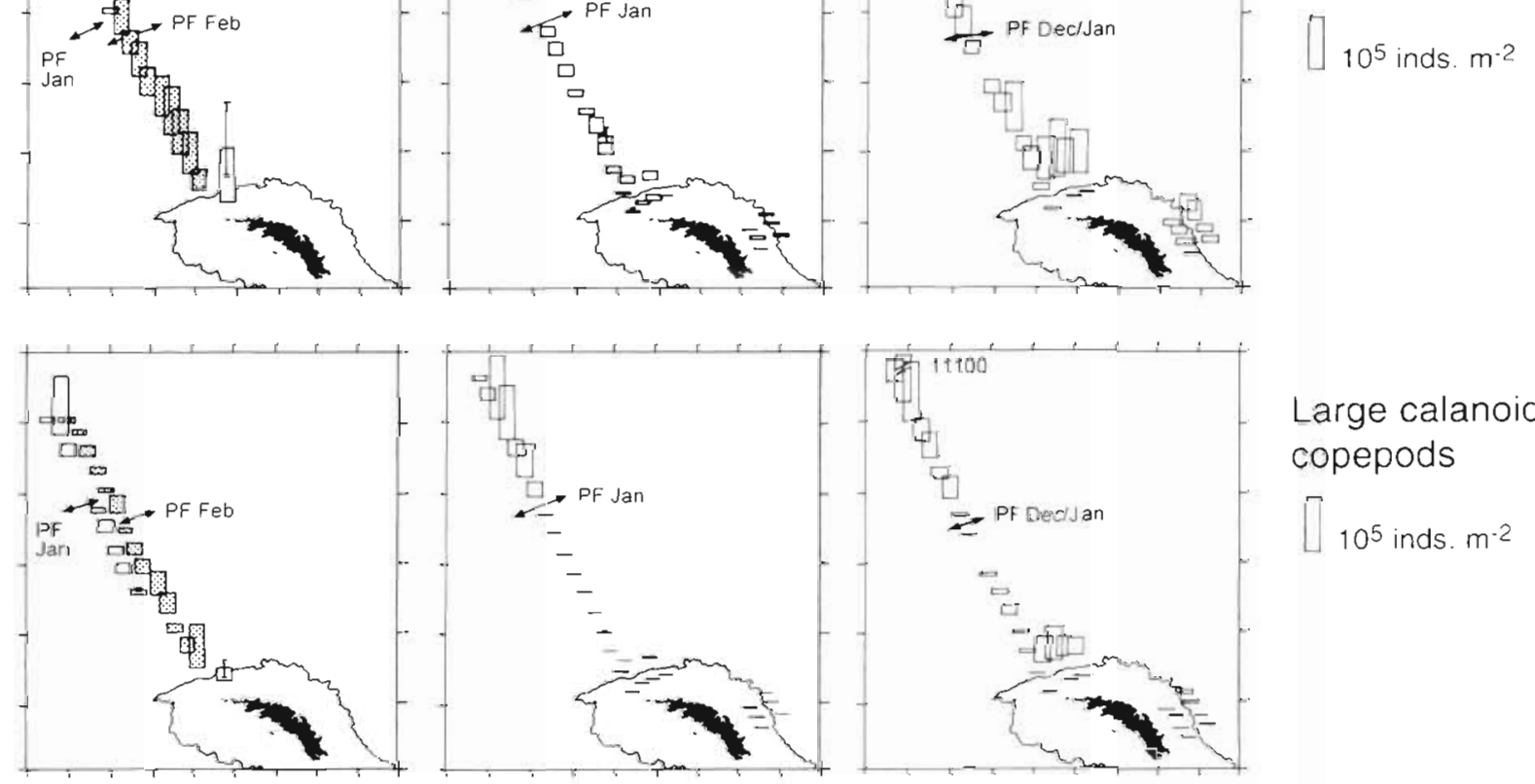

\section{Large calanoid} copepods
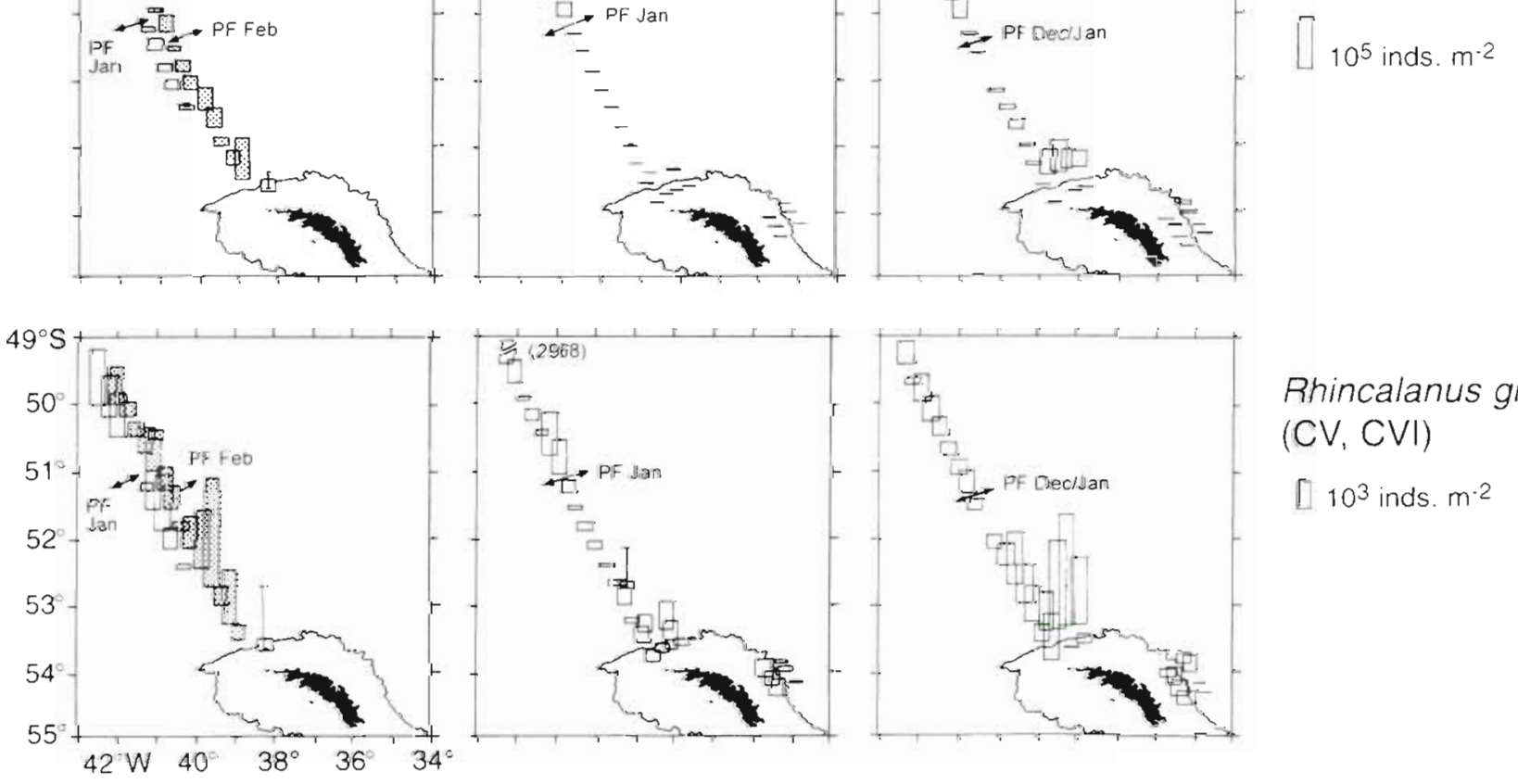

Rhincalanus gigas (CV, CVI)

[ $10^{3}$ inds. $\mathrm{m}^{-2}$

Fig. 1. Abundance of the 4 copepod groups during Jan-Feb 1994 (low krill biomass), Jan 1996 (high krill biomass) and Dec $1996-$ Jan 1997 (high krill biomass). See 'Methods: Sample analysis' for composition of copepod groups. Shaded bars: hauls in Feb 1994. The position of the Polar Front (PF) during each transect is indicated. Error bars: range in abundance between repeated hauls at a site 
Numbers of copepods from each haul were compared with 2 acoustic indices of krill biomass (Table 5). The first, 'biomass 1 ', was the mean value along the transect line spanning $5 \mathrm{~km}$ either side of the station. The second, 'biomass 2', integrated over a much wider area. Thus, the entire acoustic track south of the Polar Front was divided into 6 regions, namely eastern shelf, eastern oceanic, western shelf, western oceanic, southern half of the Polar Front transect and northern half of the Polar Front transect. Each of these acoustic regions thus encompassed either 3 or 4 net stations.

The full set of selected predictor variables is listed in Table 5. During both the 1996 and 1997 cruises, regional estimates of krill biomass were not related significantly to physical factors or to chl a concentrations. Also, the 2 years showed the same directional relationships between copepods, krill and environmental factors. Mann-Whitney $U$-tests on the 2 years failed to reveal statistically significant differences for any of the predictor variables other than salinity, so the 2 data sets

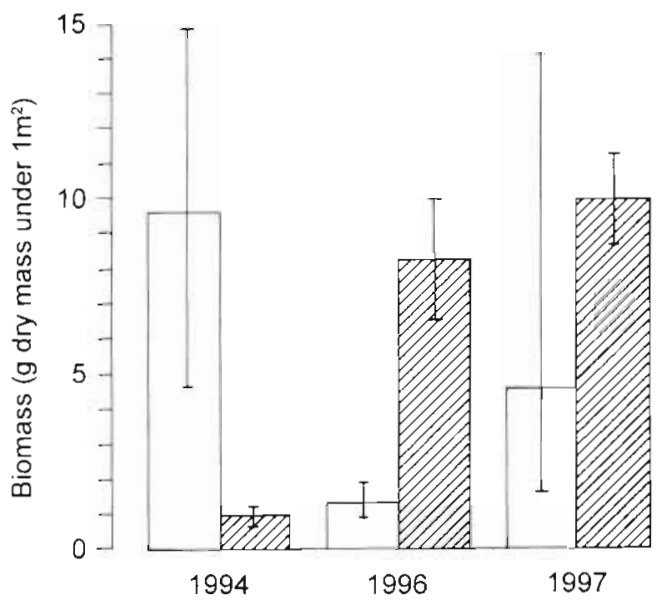

Fig. 2. Interannual changes in biomass of copepods (open bars) and krill (hatched bars). Copepod values are medians with interquartile ranges from all hauls south of the Polar Front, and krill values are weighted means with standard deviations along acoustic transects north of the island

Table 4. Comparison of copepod abundance (median no. $\mathrm{m}^{-2}$ within top $200 \mathrm{~m}$, based on $200 \mu \mathrm{m}$ mesh nets only) from hauls south of the Polar Front during the low krill year, 1994, and the high krill years, 1996 and 1997. Interquartile ranges are given in parentheses. The 1996 and 1997 hauls in the eastern area (see Fig. 1) are not included here because this area was not sampled in 1994. n: number of net hauls

\begin{tabular}{|c|c|c|c|c|}
\hline Copepod group & $\begin{array}{c}1994 \\
(n=17)\end{array}$ & $\begin{array}{c}1996 \\
(\mathrm{n}=19)\end{array}$ & $\begin{array}{c}1997 \\
(\mathrm{n}=14)\end{array}$ & $\begin{array}{c}1996-1997 \text { mean as a } \\
\% \text { of } 1994 \text { value }\end{array}$ \\
\hline Oithona spp. & $\begin{array}{c}136000 \\
(88768-167443)\end{array}$ & $\begin{array}{c}51200 \\
(3016-66254)\end{array}$ & $\begin{array}{c}72170 \\
(36430-107938)\end{array}$ & 45 \\
\hline Small calanoid & $\begin{array}{c}81200 \\
(59933-108654)\end{array}$ & $\begin{array}{c}13800 \\
(7758-23400)\end{array}$ & $\begin{array}{c}32495 \\
(13339-82285)\end{array}$ & 29 \\
\hline Large calanoid & $\begin{array}{c}17883 \\
(10158-30503)\end{array}$ & $\begin{array}{c}1205 \\
(699-2201)\end{array}$ & $\begin{array}{c}8186 \\
(1645-34558)\end{array}$ & 26 \\
\hline $\begin{array}{l}\text { Rhincalanus gigas } \\
\text { (CV plus CVI) }\end{array}$ & $\begin{array}{c}710 \\
(444-2157)\end{array}$ & $\begin{array}{c}479 \\
(246-1058)\end{array}$ & $\begin{array}{c}1463 \\
(663-2193)\end{array}$ & 136 \\
\hline Total & 235793 & 66684 & 114314 & 38 \\
\hline
\end{tabular}

Table 5. Mesoscale data for 1996 and 1997 combined to compare log copepod abundance with log krill biomass, environmental variables and $\mathrm{chl} a$ with a simple least squares regression. Krill biomass was obtained in 2 ways: 'biomass 1 ' was the mean acoustic biomass along the transect line $5 \mathrm{~km}$ either side of the station, and 'biomass 2 ' was the mean biomass over a wider area (see 'Methods'). Adjusted $r^{2}$ values are given for only the significant results. (-): negative relationship, (+): positive relationship; $\cdot$ significant $(p<0.05), \cdots$ highly significant $(p<0.01)$

\begin{tabular}{|c|c|c|c|c|c|}
\hline Predictor variable & $\begin{array}{l}\log _{10}(\text { total } \\
\text { copepods) }\end{array}$ & $\begin{array}{c}\log _{10}(\text { Oithona } \\
\text { spp.) }\end{array}$ & $\begin{array}{c}\log _{10}(\text { small cala- } \\
\text { noid copepods) }\end{array}$ & $\begin{array}{c}\log _{10}(\text { large cala- } \\
\text { noid copepods) }\end{array}$ & $\begin{array}{l}\log _{10}(\text { Rhincalanus } \\
\text { gigas CV plus CVI) }\end{array}$ \\
\hline $\log _{10}($ krill biomass 1$)$ & $0.28(-)^{\cdots}$ & $0.31(-)^{*}$ & $0.21(-)^{\cdots}$ & & \\
\hline $\log _{10}($ krill biomass 2$)$ & $0.33(-) \cdots$ & $0.29(-)^{\cdots}$ & $0.24(-)^{\cdots}$ & $0.15(-)^{\bullet}$ & \\
\hline \multicolumn{6}{|l|}{ Minimum temperature in top $200 \mathrm{~m}$} \\
\hline Mean temperature in top $20 \mathrm{~m}$ & $0.22(+)^{*}$ & $0.16(+)^{\circ}$ & $0.24(+) \cdots$ & $0.19(+)^{\circ}$ & $0.40(+)^{\cdots}$ \\
\hline Salinity at $20 \mathrm{~m}$ & $0.21(+)^{\circ}$ & $0.21(+)^{\circ}$ & $0.33(+) \cdots$ & $0.14(+)^{\circ}$ & \\
\hline Mean chl $a$ in top $80 \mathrm{~m}$ & & & $0.15(+)^{\circ}$ & & \\
\hline Maximum chl a & & & $0.15(+)^{\circ}$ & & $0.12(+)^{\bullet}$ \\
\hline
\end{tabular}




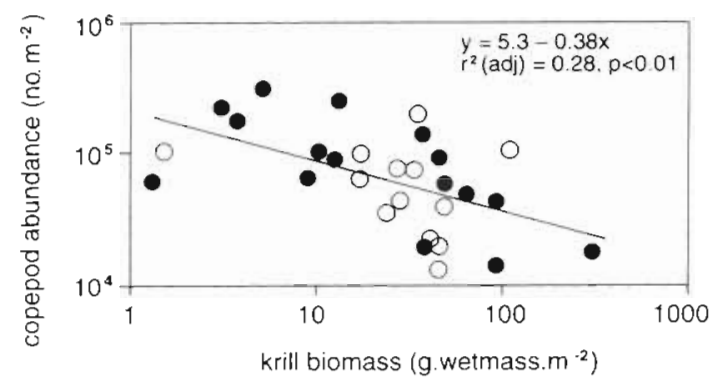

Fig. 3. Abundance of total copepods in relation to mean biomass of krill, during the sampling in 2 high krill abundance years, 1996 (O) and 1997 (•). Each point represents a net haul south of the Polar Front for copepod abundance: corresponding krill biomass is from an acoustic transect $5 \mathrm{~km}$ either side of the net station. Krill and copepods are not expressed in the same units because of errors inherent in such conversions

were combined to ease presentation (Table 5). The smaller copepods were clearly related (negatively) more strongly to krill than to temperature, salinity or food, although Rhincalanus gigas (CV plus CVI) was strongly related (positively) to temperature. Fig. 3 summarises the relationship between total copepod abundance (i.e. all 4 size groups pooled) and krill biomass.

\section{(3) Mesoscale survey, 1981}

Fig. 4 shows the distributions of zooplankton in relation to their physical/biological environment during the semi-synoptic grid survey. Both this net sampling and the acoustic transects which were run between stations (Murphy et al. 1991) show that the main concentrations of krill were to the north and east of South Georgia. These regions of high krill abundance coincided with low copepod numbers (Fig. 4). The most abundant macroplankton (i.e. Themisto gaudichaudi, Thysanoessa spp., Euphausia frigida, Euphausia triacantha, Salpa spp. and Vibilia antarctica) also tended to be rarer at a few stations just north of the island, but this was much less clear than for the copepods. Note that krill abundances are based on RMT 8 hauls; avoidance of this sampler has been shown previously (Everson \& Bone 1986), so the actual densities probably were much greater.

To examine these distributions, Atkinson et al. (1990) did a principal components analysis on $\log _{10}$ transformed abundances of the major species. When the neritic species Drepanopus forcipatus and Antarctomysis maxima were excluded, the stations separated on the first principal component (i.e. that describing most of the variability in the data set) roughly according to the total quantity of zooplankton. Five stations immediately north of the island had notably few copepods, and were outliers on the first principal component axis (Atkinson et al. 1990). The second principal component axis was linked to localised, eddy type intrusions of water of Subantarctic origin, which had a characteristic warmer water fauna. However, no environmental factors explained the areas of low copepod abundance. They were unrelated to water mass distribution, phytoplankton biomass or species composition (Fig. 4. Theriot \& Fryxell 1985, Priddle et al. 1986) or the characteristic neritic or oceanic zooplankton assemblages (Atkinson \& Peck 1990, Atkinson et al. 1990). However, the principal components analysis implicated krill with the areas of low copepod abundance across the entire survey grid. This is supported by regressions of the copepod size groups in relation to krill and environmental factors (Table 6). Copepod abundance was linked more closely to that of krill than to chl a or environmental factors. This result held whether krill abundance was obtained from the RMT 8 net mounted just below the RMT 1 or krill biomass was derived from the transect line $50 \mathrm{~km}$ either side of each station.

The most striking low copepod area is the one just north of the island (Fig. 4). If this is interpreted in relation to krill distribution, based on both this 1981 survey and the large quantity of krill data published for this region, some striking parallels emerge. Earlier this century, the region just north of the island was the

Table 6. Mesoscale data for 1981 comparing log abundance of copepods with log krill abundance, krill acoustic biomass, environmental variables and chl a using a simple least squares regression analysis. Krill acoustic biomass was calculated as an average of those inter-station acoustic transects (each $50 \mathrm{~km}$ long) which were immediately adjacent to the station. Adjusted $\mathrm{r}^{2}$

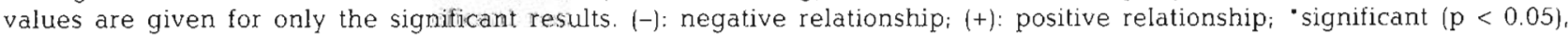
- highly significant $(p<0.01)$

\begin{tabular}{|c|c|c|c|c|c|}
\hline Predictor variable & $\begin{array}{l}\log _{10} \text { (total } \\
\text { copepods) }\end{array}$ & $\begin{array}{c}\log _{10}(\text { Oithona } \\
\text { spp.) }\end{array}$ & $\begin{array}{l}\log _{10} \text { (small cala- } \\
\text { noid copepods) }\end{array}$ & $\begin{array}{l}\log _{10}(\text { large cala- } \\
\text { noid copepods) }\end{array}$ & $\begin{array}{l}\log _{10}(\text { Rhincalanus } \\
\text { gigas CV plus CVI) }\end{array}$ \\
\hline $\log _{10}($ krill abundance +1$)$ & $0.13(-)^{\cdots}$ & $0.18(-)^{\cdots}$ & $0.14(-)^{*}$ & $0.16(-) \cdot \cdots$ & $0.22(-) \cdot \cdot$ \\
\hline Krill acoustic biomass & $0.17(-)^{\cdots}$ & $0.15(-) \cdots$ & $0.16(-)^{\cdots}$ & $0.21(-)^{\cdots}$ & $0.17(-)^{\cdots}$ \\
\hline Temperature at $20 \mathrm{~m}$ & $0.08(+)^{\circ}$ & & $0.081+]^{\circ}$ & $0.09(+)$ & $0.11\left\{+j^{\circ}\right.$ \\
\hline $\begin{array}{l}\text { Minimum temperature in top } 200 \mathrm{~m} \\
\text { Salinity at } 20 \mathrm{~m}\end{array}$ & $0.09(+)^{\circ}$ & & $0.13(+) \cdots$ & & \\
\hline
\end{tabular}



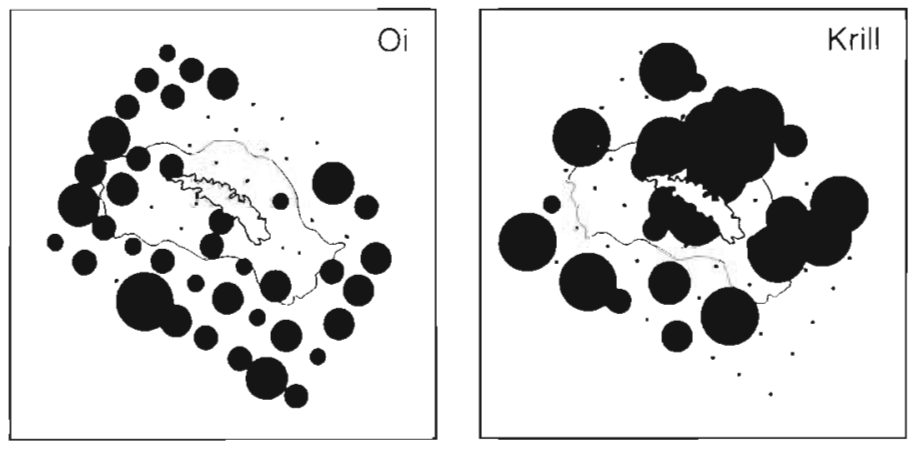

\begin{tabular}{ll}
$\begin{array}{l}\text { Euphausla } \\
\text { superba } \\
\text { (Kril) }\end{array}$ & \multicolumn{1}{c}{ Macroplankton } \\
(Macro)
\end{tabular}

Oithona spp. (Oi)

Smail calanoid copepods (Sc

Large calanoid copepods (LC)

$<1000$

$1000-2000$

$2000-5000$

$5000-10000$

$10000-20000$

$>20000$
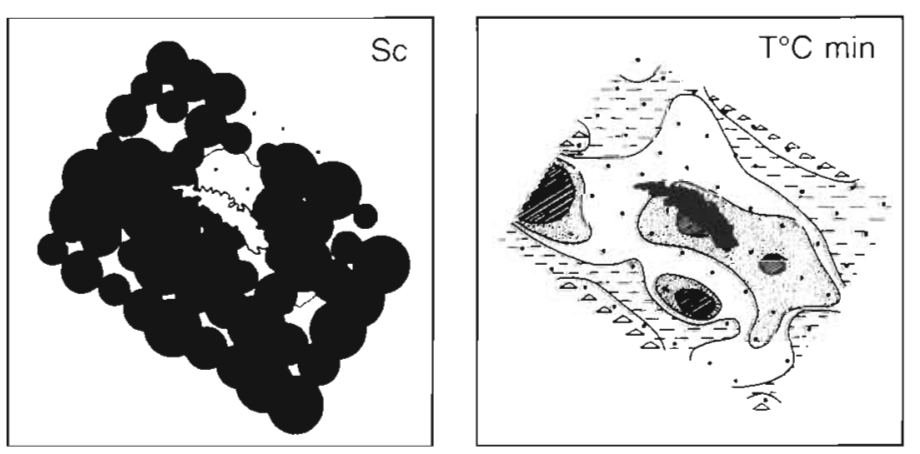

Minimum temperature
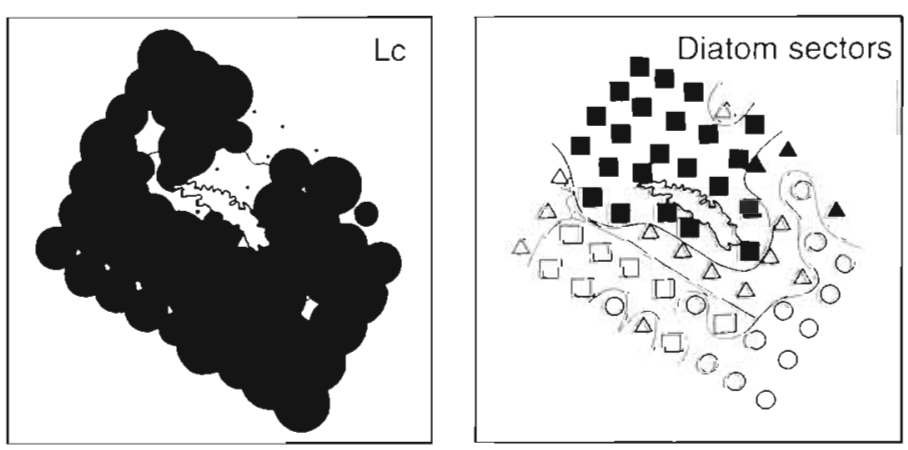

Diatom sectors
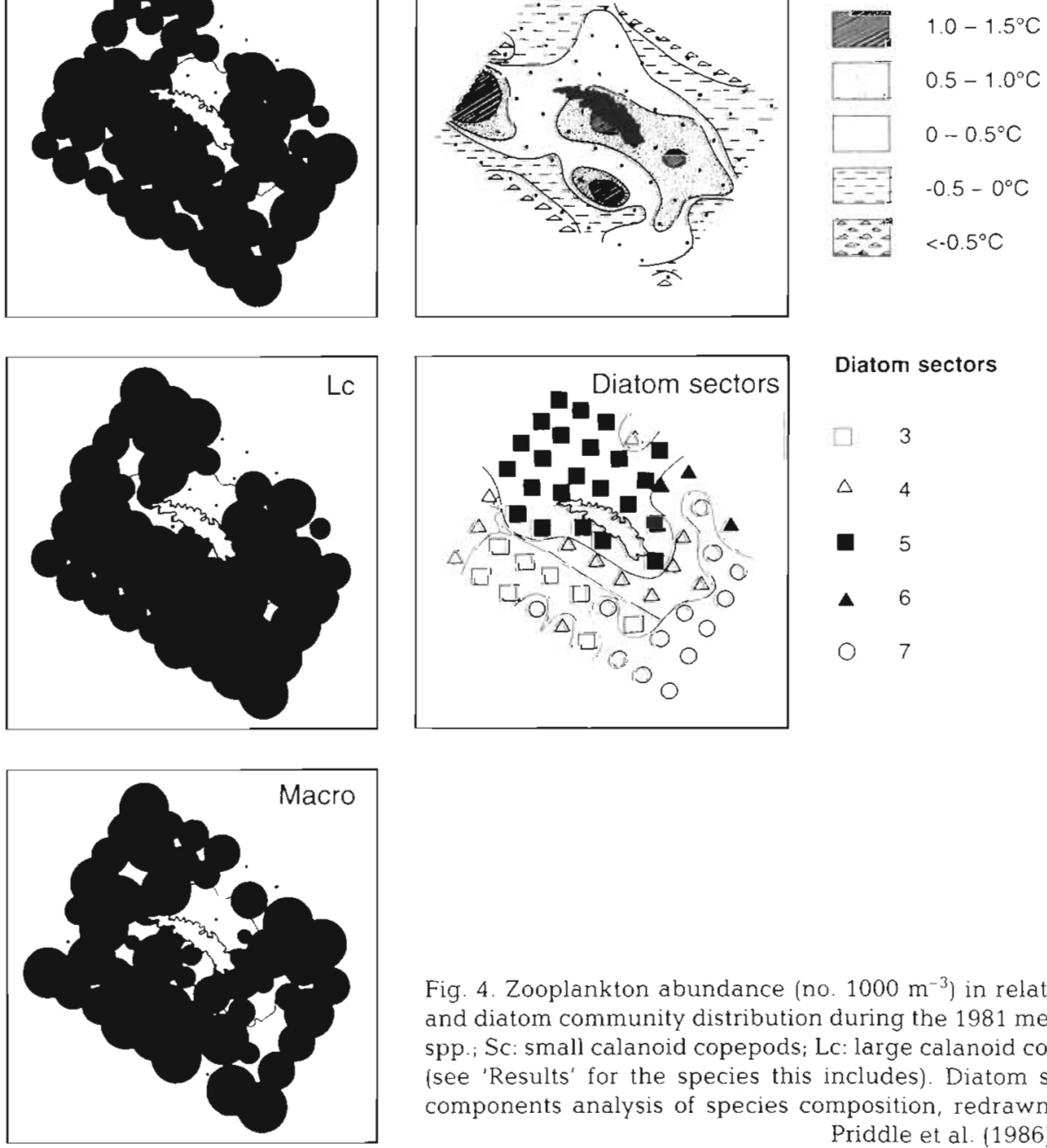

Fig. 4. Zooplankton abundance (no. $1000 \mathrm{~m}^{-3}$ ) in relation to krill abundance, temperature and diatom community distribution during the 1981 mesoscale synoptic survey. Oi: Oithona spp.; Sc: small calanoid copepods; Lc: large calanoid copepods. Macro: total macroplankton (see 'Results' for the species this includes). Diatom sectors are the result of a principal components analysis of species composition, redrawn from Theriot \& Fryxell (1985) and Priddle et al. (1986)

main fishing ground for krill-eating whales, and the site for most sightings of whales and surface krill swarms (Mackintosh 1973, Everson 1984). More recently, the shelf break just north of South Georgia has been the principal site for the South Georgia krill fishery, and of the highest catches (CCAMLR 1996,
Trathan et al. 1998). Both historical and recent net sampling and acoustic surveys have shown that the region just north of South Georgia tends to support consistently higher concentrations of krill than elsewhere around the island (Hardy \& Gunther 1935, Marr 1962, Mackintosh 1973, Pakhomov et al. 1997a). 
Table 7 Multiple regression of $\log _{10}$ copepod abundance against predictor variables for the 1981 and $1996-1997$ data sets $t$ values are of coefficients of the individual parameters, and adjusted $r^{2}$ values and $F$ ratios are for the fitted model. ' $\mathrm{p}<0.05$, $\cdots p<0.01$

\begin{tabular}{|c|c|c|c|c|c|}
\hline Year & $\begin{array}{l}\text { Response variable } \\
\qquad(\log )\end{array}$ & $\begin{array}{l}\text { Significant } \\
\text { predictor variables }\end{array}$ & $t$ value & $\begin{array}{c}r^{2}(\text { adj. }) \\
(\%)\end{array}$ & Fratio \\
\hline \multirow[t]{5}{*}{1981} & Total copepods & Krill $\cdot$ & -3.4 & 16 & 12 \\
\hline & Oithona spp. & Krill $\cdot$ & -3.1 & 14 & 10 \\
\hline & Small calanoid copepods & $\begin{array}{l}\text { Krill }{ }^{*} \\
\text { Min temperature } .\end{array}$ & $\begin{array}{r}-2.9 \\
2.5\end{array}$ & 22 & 8.8 \\
\hline & Large calanoid copepods & Krill $\cdots$ & -3.8 & 19 & 14 \\
\hline & Rhincalanus gigas CV plus CVI & $\begin{array}{l}\text { Krill }{ }^{\circ} \\
\text { Mixed layer temperature }\end{array}$ & $\begin{array}{r}-2.9 \\
2.0\end{array}$ & 21 & 8 \\
\hline \multirow[t]{5}{*}{$1996-1997$} & Total copepods & Krill $\cdot$ & -3.7 & 48 & 13 \\
\hline & Oithona spp. & Krill $\cdot$ & -3.4 & 40 & 9.3 \\
\hline & Small calanoid copepods & $\begin{array}{l}\text { Krill " } \\
\text { Mixed layer temperature }\end{array}$ & $\begin{array}{r}-3.7 \\
2.2\end{array}$ & 49 & 13 \\
\hline & Large calanoid copepods & Mixed layer temperature" & 2.7 & 19 & 7.3 \\
\hline & Rhincalanus gigas CV plus CVI & Mixed layer temperature ${ }^{\cdot}$ & 4.3 & 40 & 18 \\
\hline
\end{tabular}

To disentangle the simultaneous effects of krill and environment on copepods, multiple regressions were done on both the 1981 and the 1996-1997 data sets. This analysis requires that the predictor variables are not autocorrelated ( $Z$ ar 1984). Fortunately, this was the case between the 3 subgroups of predictor variable, namely krill, physical variables and chl a concentration. Within these subgroups, however, the variables were significantly related (e.g. mixed layer temperature and salinity were strongly positively related) Therefore, for each of the copepod size groups, we performed simple least squares linear regressions of all the variables to test the strength of relationship with each. From each of the subgroups of predictor variable we then selected the one most strongly related to copepod abundance (this gave 3 potential predictor variables, a krill variable, a physical variable and a food variable). This group was further reduced by a stepwise factor analysis which eliminated those which could not explain significant variance in copepod abundance. Of the remaining significant variables, the results of the multiple regression analysis are summarised in Table 7.

\section{(4) Fine-scale horizontal distribution, 1996}

Five horizontal LHPR tows enabled us to relate copepod abundance to environmental variables and krill abundance. Slight variations in temperature were encountered in these tows through the mixed layer, but no congruence could be found between either krill or copepods and temperature or salinity, so environmental data will not be discussed further. However, 2 distinct types of krill-copepod interaction were apparent (Fig. 5).

First, within krill swarms, copepod numbers were low. We defined a swarm as $>150$ krill per $10 \mathrm{~m}^{3}$, although avoidance of the sampler, particularly in Hauls 2 and 5 during the daytime, could mean much higher true densities. Table 8 compares abundances of the 3 main copepod groups between samples within krill swarms and those outside them. (The 4th copepod group, 'Rhincalanus gigas CV plus CVI', was too rare in these samples for statistical comparisons.) The rarity of copepods within krill swarms is apparent in Table 8, and is illustrated clearly by Haul 5 (Fig. 5). In this daytime haul, krill caught by the sampler did not achieve densities sufficient for classification as a swarm, but copepods were almost absent within this aggregation.

Is the rarity of copepods within swarms a sampling artifact? If large numbers of krill are trapped in the cod end of the sampler, this might reduce its filtration and allow copepods and krill to be recirculated within the sampler rather than be flushed into the cod end. Alternatively, while on the cod end take-up spool, the krill could have prevented the 2 layers of netting from enveloping the catch fully, allowing copepods to be washed out. Two points, however, argue against artifacts. First, copepods were often rare just outside krill swarms, as well as within them (Fig. 5). This is again illustrated by Haul 5, where the numbers of calanoid copepods immediately adjacent to the krill concentration (i.e. near the shaded area in Fig 5) were lower than those further away (Fig. 5). The second point is again derived from Haul 5. Rather few krill (often $<10$ ind.) were present in the individual samples within the swarm. In the other hauls, this modest density of 
krill tended to be associated with elevated numbers of copepods (see below), so sampling artufacts cannot explain this haul.
The second type of krill-copepod interaction occurred outside krill swarms. Here, lower density aggregations of krill tended to be associated with elevated

Table 8. Krill-copepod relationships insıde and outsıde of krill swarms in 4 of the 5 horizontal LHPR tows in 1996 Ratios for each copepod group are its median abundance withın a knll swarm ( $>150 \mathrm{krlll}$ per $\left.10 \mathrm{~m}^{3}\right)$ to median abundance outside a krill swarm (<150 krill per $10 \mathrm{~m}^{3}$ ). To reduce the problem of 'edge effects' of knll swarms, the 2 samples either side of each krill swarm were omitted from the analysis. -: copepods were too rare for statıstıcal testıng (l e average for haul $<50 \mathrm{und}$ per $10 \mathrm{~m}^{3}$ ) Each palr of medians was compared with a Mann-Whitney test, and probability values signufy signuficant differences Only a single sample with a krill swarm in Haul 4 precluded this test Haul 5 had no krill densities defined here as swarms (but see 'Results' and Fig 5 for description of this haul)

\begin{tabular}{|lccc|}
\hline LHPR & \multicolumn{2}{c|}{$\begin{array}{c}\text { Ratio of median abundance (samples in krill swarm samples outsıde krill swarm) } \\
\text { Oithona spp }\end{array}$} & $\begin{array}{c}\text { Small calanold copepods } \\
\text { Large calanoid copepods }\end{array}$ \\
\hline Haul 1 & $0.15(\mathrm{p}<0$ 05) & 073 & - \\
Haul 2 & $0.29(\mathrm{p}<001)$ & $050(\mathrm{p}<0.05)$ & - \\
Haul 3 & 0.095 ( $\mathrm{p}<0.01)$ & - & 051 (no test) \\
Haul 4 & 0.132 (no test) & 041 (no test) \\
\hline
\end{tabular}

Haul 2

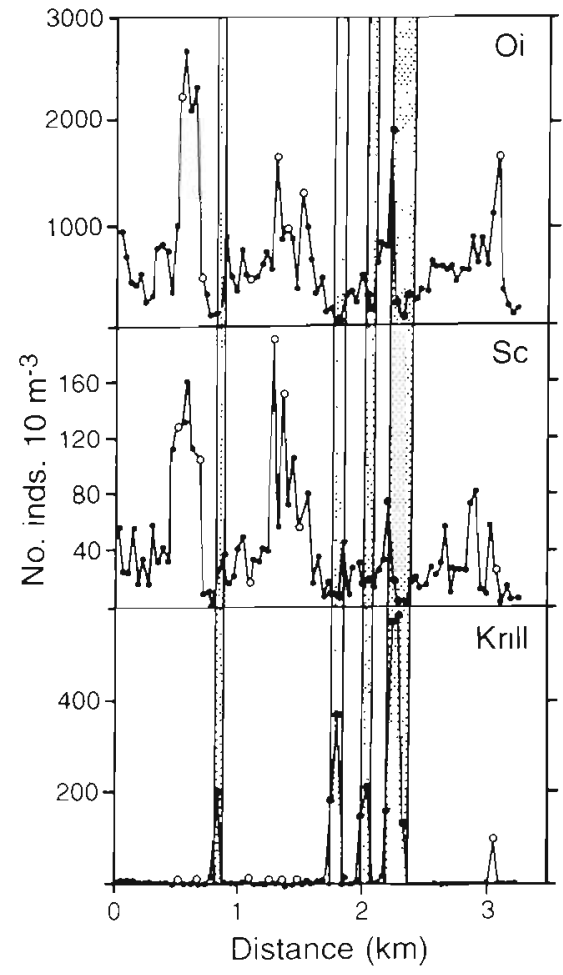

- sample with $<4$ krill $10 \mathrm{~m}^{-3}$

- sample with $4-150 \mathrm{krill} 10 \mathrm{~m}^{-3}$

- sample with >150 krill $10 \mathrm{~m}^{-3}$
Haul 4

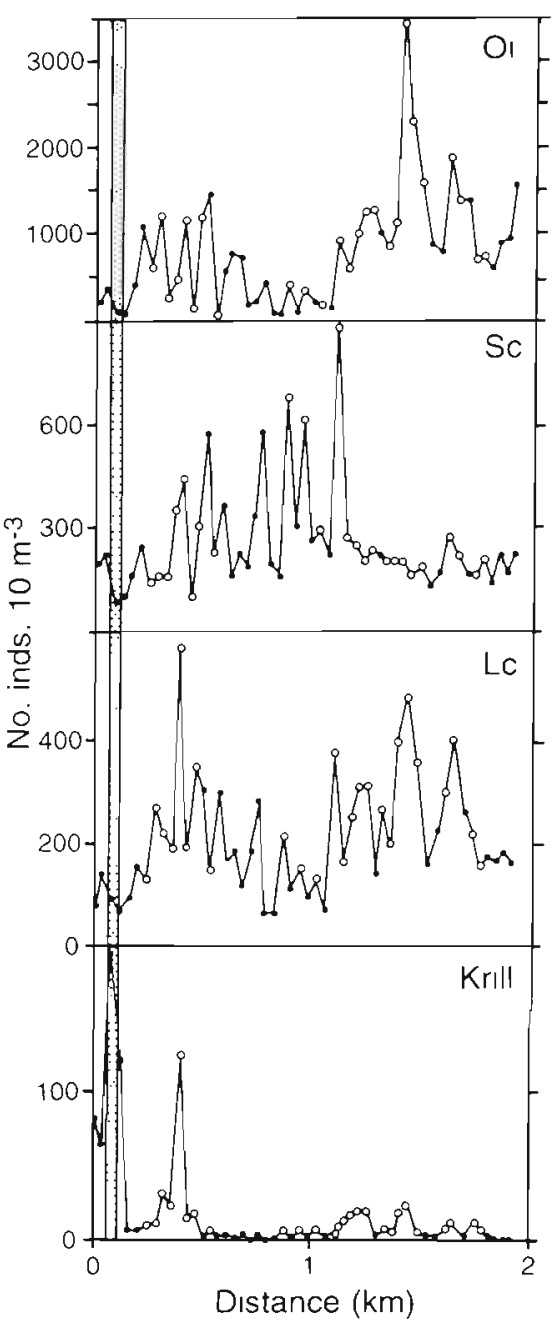

Haul 5

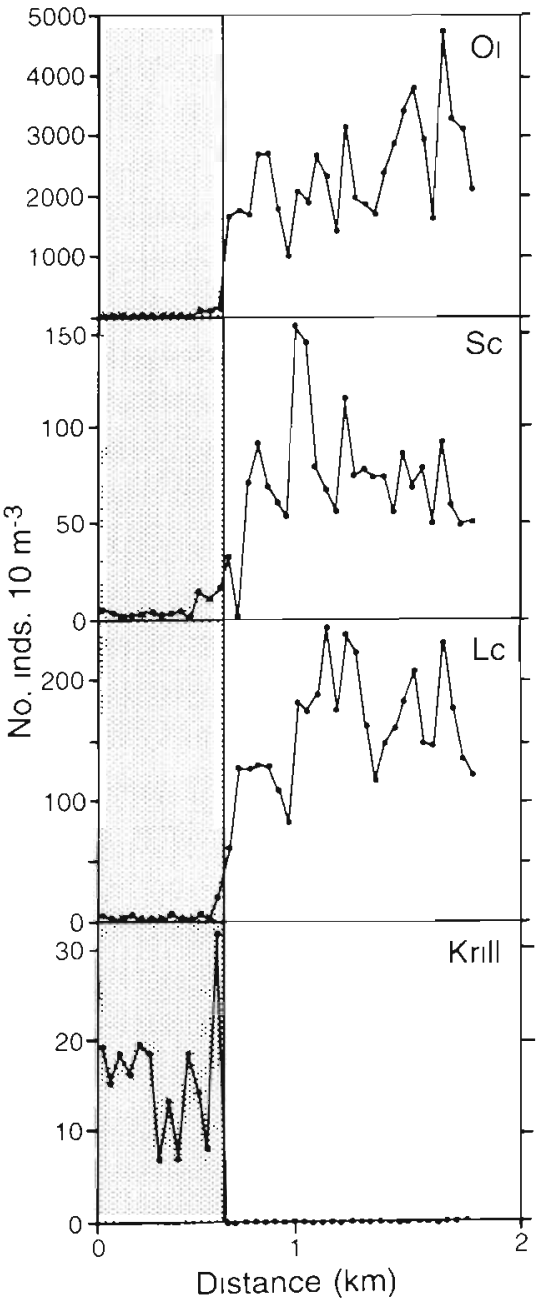

Fig. 5. Horizontal distribution of Oithona spp (Ol). small calanold copepods (Sc). large calanold copepods (Lc) and krill on 3 of the 5 horizontal hauls at $30 \mathrm{~m}$ (see Table 3) Shaded areas represent krill swarms (see 'Results') Knll abundance (>4, 4-150 and $>150 \mathrm{krnll}$ per $10 \mathrm{~m}^{3}$ ) is shown for each data point 
Table 9. Krill-copepod relationships outside krill swarms in 4 of the 5 horizontal LHPR tows in 1996. Ratios for each copepod group are its median abundance in samples with $4-150 \mathrm{krill}$ per $10 \mathrm{~m}^{3}$ to median abundance in samples with 4 krill per $10 \mathrm{~m}^{3}$ Each pair of medians was compared with a Mann-Whitney test (see 'Results') and probability values signify significant differences. -: copepods were too rare for statistical testing (i.e. average for haul $<50$ ind. per $10 \mathrm{~m}^{3}$ ). Note that in Haul 3 there were only 2 samples with $4-150 \mathrm{krill}$ per $10 \mathrm{~m}^{3}$

\begin{tabular}{|lccc|}
\hline $\begin{array}{l}\text { LHPR } \\
\text { haul }\end{array}$ & \multicolumn{2}{c|}{$\begin{array}{c}\text { Ratio of median abundance (samples with abundant krill: samples with rare krill) } \\
\text { Oithona spp. }\end{array}$} & $\begin{array}{l}\text { Small calanoid copepods } \\
\text { Large calanoid copepods }\end{array}$ \\
\hline Haul 1 & $1.8(p<0.01)$ & $1.8(p<0.01)$ & - \\
Haul 2 & $2.3(p<0.05)$ & $3.3(p<0.05)$ & - \\
Haul 3 & 2.6 & - & $1.4(p<0.01)$ \\
Haul 4 & 1.2 & 1.1 & \\
\hline
\end{tabular}

copepod numbers. To test this statistically we first excluded samples within swarms and the 2 samples either side of them, to reduce swarm effects. Haul 5 was also excluded, as half of it was characteristic of a krill swarm, as described previously, and no krill were found in the other half. The remaining samples were divided into 2 groups: those with elevated krill abundance ( 4 to $150 \mathrm{krill}$ per $10 \mathrm{~m}^{3}$ ) and those with scarce or no krill (i.e. $<4$ krill per $10 \mathrm{~m}^{3}$ ). These groups are denoted by different symbols in Fig. 5. For each copepod group, the null hypothesis was that their abundance was similar regardless of krill abundance. In 5 of the 8 available comparisons the null hypothesis was rejected (Table 9), so outside swarms krill tended to associate with high numbers of copepods.

\section{(5) Fine-scale vertical distribution, 1994-1996}

During the high krill year, 1996, krill swarms were detected acoustically in the vicinity of both the shelf and oceanic monitoring sites, and were caught in low numbers during the LHPR profiling. Krill were not caught by the LHPR, however, during the low krill year, 1994. Fig. 6 shows clear evidence for diel vertical migration and overall deeper living populations during 1996, as compared to 1994. This is despite much lower chl a concentrations in 1996 (see 'Results: (1) Interannual variability; 1994-1996-1997').

\section{(6) Fine-scale vertical distribution, 1990 diel series}

During January 1990 a series of 17 LHPR profiles was obtained. Each haul included a pair of double oblique tows to $200 \mathrm{~m}$ depth and most were obtained within a single 24 h period. The vertical distributions of the large copepod species in relation to their gut fullness, food availability and water column structure have been described previously (Atkinson et al. 1992). However, during one of the hauls, the LHPR encoun- tered a krill aggregation in the top $100 \mathrm{~m}$ layer. In the ascent portion of the haul, where most krill were caught, this aggregation coincided with an anomalous vertical distribution of copepods. This single profile, which showed a completely different vertical distribution from the other 16, was excluded as an outlier in the analysis of Atkinson et al. (1992), but is shown for comparison in Fig. 7. The 4 copepod species analysed showed varying degrees of migration upwards during the nighttime period, with migration of Calanus propinquus and Calanus simillimus being of greater amplitude than that of Calanoides acutus and Rhincalanus gigas. However, the haul where the krill

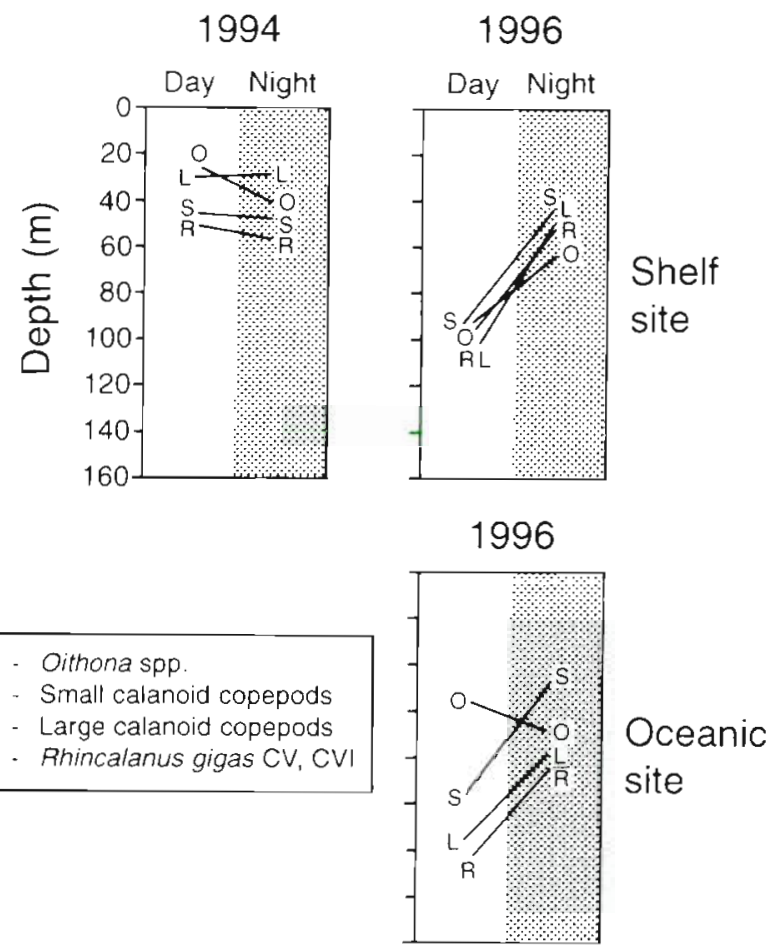

Fig. 6. Median depths of the 4 copepod groups during daytime and righttime LHPR hauls in 1994 and 1996. Day and night profiling was not undertaken at the oceanic site in 1994 


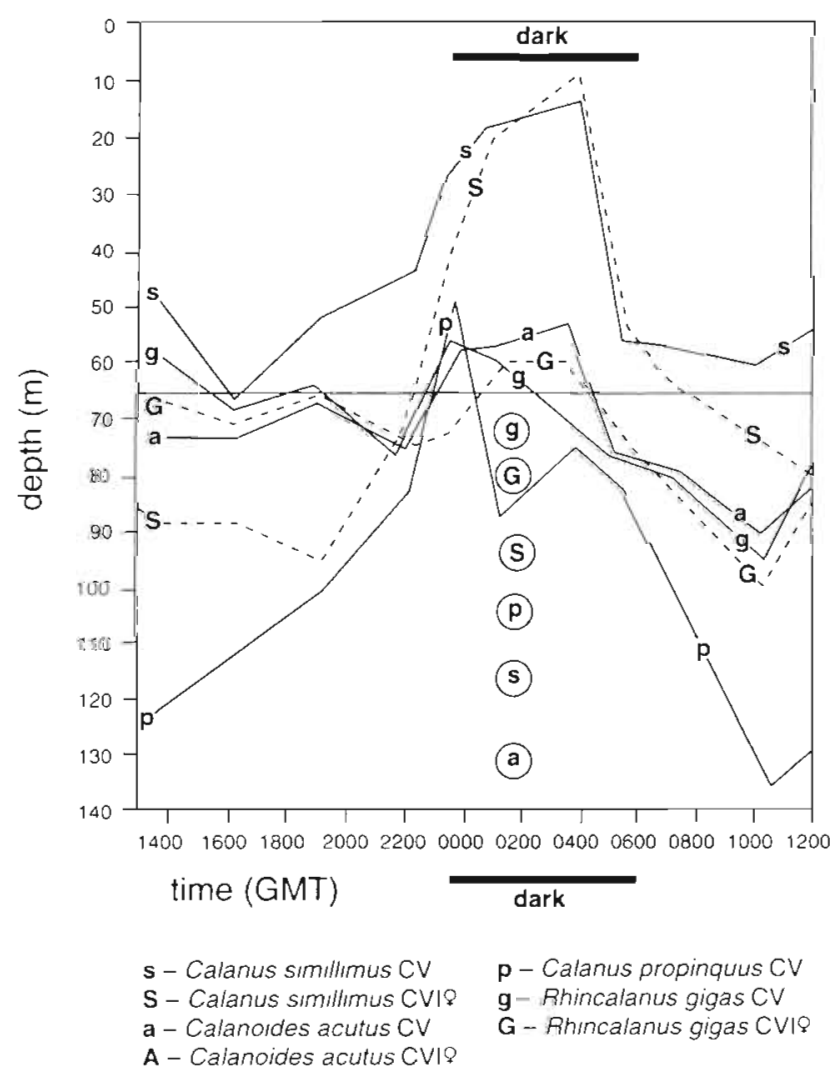

Fig. 7. Median depths of major copepods during a diel series of LHPR profiles in early January 1990. Most of the values are the averages of the downward and upward profiles of the hauls (see Atkinson et al. 1992 for details). The symbols are circled for the profile where large numbers of krill were encountered. The bottom of the upper mixed layer is denoted by a horizontal line

aggregation was encountered reveals median depths of the copepods between 10 and $100 \mathrm{~m}$ greater than those from the other nighttime profiles.

\section{DISCUSSION}

Copepods varied greatly in abundance: over 10 -fold interannually and over a 1000 -fold on a mesoscale and a horizontal fine scale. These differences are much larger than either seasonal or large-scale regional changes in mean abundance of single copepod species (Marin 1987, Schnack-Schiel \& Hagen 1995, Atkinson et al. 1997, Ward et al. 1997). The inverse relationship between krill and copepods occurred repeatedly and across a wide range of scales. Here, we examine some possible reasons.

One possibility, which does not invoke any interaction between the 2 groups, is that some environments are suited to krill and others more suited to copepods. Hosie (1994) suggested this as one explanation for low copepod numbers in a high krill region over the shelf break at Prydz Bay (Indian Ocean sector): it was a transition zone between shelf and oceanic assemblages and thus properly suited to neither. This cannot explain our results, because the high krill biomass was in specific regions crossing both shelf and ocean, and these transcend the distributions of water masses (Priddle et al. 1986, Atkinson et al. 1990), phytoplankton biomass and composition (Makarov et al. 1984, Priddle et al. 1986), and the characteristic neritic, Antarctic and Subantarctic mesozooplankton communities (Atkinson \& Peck 1990, Atkinson et al. 1990). Likewise, the fine-scale discontinuities between krill swarms and copepods (e.g. Haul 5 in Fig. 5) were so sharp and unrelated to any physical structure that they could not have been caused by mutually incompatible habitat preferences. It is probably the mobility of krill which meant that their fine- and mesoscale distribution was unrelated to water masses around South Georgia. This is fortunate because it allowed us to separate the relative influence of krill and bottom-up controls on copepod abundance. Thus the inverse relationship between krill and copepods, as well as occurring across a wide range of scales, was an effect distinguishable from environmental factors.

From this we are forced to conclude that krill must have had a direct effect on copepods. However, in the case of the interannual variability, correlation need not necessarily mean causation. The rarity of copepods in the 2 high krill years could have also resulted from differences in physical environment, or in timing of phytoplankton blooms, which affected one more than the other. Despite this caveat, there is little reasonable doubt that, at meso- or finer scales, areas of high krill abundance are detrimental to copepods.

There are few data on krill-copepod interactions with which to compare these results. At the scale of a krill swarm, a key scale at which interactions could occur, this is particularly the case (see Hardy 1936. Shulenburger et al. 1984). Schnack (1985) reported a low abundance of copepods in krill swarms, but no supporting data were supplied. We also found that copepods were rare in krill swarms (Fig. 5, Table 8). This may be because either the copepods had migrated out of their way or they had been eaten. Even a modest swarm density (50 ind. $\mathrm{m}^{-3}$ of $100 \mathrm{mg}$ dry mass krill) with clearance rates on copepods as measured in 1996 experiments (Atkinson \& Snÿder 1997) would remove all available food in just $1 \mathrm{~d}$ if the swarm did not move. Also, the fine-scale vertical distributions (Figs. 6 \& 7) show evidence that the diel vertical migration pattern of copepods was affected by krill. Whether copepods had been eaten or migrated down to less productive feeding areas, the presence of layers or swarms of krill is probably detrimental. 
The only positive correlation between krill and copepods was outside of swarms, where krill tended to associate with high copepod concentrations (Fig. 5 , Table 9). This contrast between swarming and more dispersed krill could be explained by the hypotheses of Pavlov (1969) and Hamner et al. (1983): that although krill do feed in swarms, they swarm mainly to reduce predation risk, reproduce, migrate or to search for food. They then disperse to increase food intake. The low chl a concentrations sometimes associated with krill swarms (Antezana \& Ray 1984, Miller \& Hampton 1989, Kopczynska 1992) and the low copepod numbers (Fig. 5) suggest a poor environment for continued feeding. Because euphausiids are good swimmers with complex foraging behaviour (Hamner et al. 1983, Price 1989), successful exploitation of food patches could explain their high intake in low average food concentrations (e.g. McClatchie 1985, Price et al. 1988). The positive relationship between non-swarming krill and copepods could be either because krill located aggregations of copepod prey or that both were attracted to the same patches of microplankton.

This was the only positive relationship we found between krill and copepods; the pervasive relationship was negative. Was this due to competition for food, predation, or both? Distribution data alone cannot be used to differentiate these causes, as their effects could be similar. Also, the events causing the observed distributions would have occurred in the days and weeks before sampling, so it is unwise to speculate on these. Krill swarms are able to deplete microplankton greatly (Antezana \& Ray 1984, Miller \& Hampton 1989), potentially out-competing the copepods which rely on this as food (Lopez et al. 1993, Atkinson et al. 1996, Ward et al. 1996).

Alternatively, several strands of evidence point to direct predation. Gut contents analysis demonstrates that krill indeed eat other zooplankton. The only 2 such analyses from the South Georgia region, made during winter and summer non-bloom conditions, both showed that crustaceans featured strongly in their diet (Nishino \& Kawamura 1994, Pakhomov et al. 1997a). Evidence is mounting, both from gut contents analysis and from energy budgets, that outside of bloom periods krill can be omnivorous (see Atkinson \& Snÿder 1997. Pakhomov et al. 1997a, Perissinotto et al. 1997). The in situ ingestion rates of algal carbon by krill measured in our 1996 survey were well below their estimated metabolic costs, suggesting a non-algal diet (Atkinson \& Snÿder 1997). This is supported by concurrent measurements of the biomarker composition of their fatty acids (G. C. Cripps, British Antarctic Survey, unpubl. data). Also, during 1996, the in vitro clearance rates of krill on small copepods, combined with acoustic estimates of their regional average bio- mass, suggested that they could potentially remove $\sim 40 \%$ of copepod population per month. This impact is much greater than those from rarer and smaller species such as Themisto gaudichaudii (Pakhomov \& Perissinotto 1996) and Eukrohnia hamata (Oresland 1990), and would be a significant loss term for many Southern Ocean copepods with $\sim 1$ yr life cycles. Opinion is divided as to how well laboratory results can be applied to nature, but the rates measured by Atkinson \& Snyder (1997) suggest that krill have the potential to eat copepods at rates which would deplete their populations severely.

The different responses of the various copepod size fractions to krill (Table 7) could also imply predation. Rhincalanus gigas CV plus CVI was the only copepod group not eaten in the 1996 experiments, probably because it was so large it could escape predation by the juvenile krill (Atkinson \& Snÿder 1997). This group was also the only one not depleted in the 2 high krill years (Table 4) and was strongly related to physical factors as well as to krill. Copepod biomass is exceptionally high at South Georgia (Ward et al. 1995, Atkinson et al. 1996, Pakhomov et al. 1997b), so we speculate that, outside of bloom periods, small copepods are a supplementary food source. In other regions, copepods have been found in the guts of krill (e.g. Marr 1962, Hopkins 1985, Hopkins \& Torres 1989, Nordhausen \& Huntley 1992, Hopkins et al. 1993a, b, Huntley et al. 1994), although herbivory may prevail in the Antarctic Peninsula area (Quetin \& Ross 1991). The extent to which krill predation impacts copepods would vary locally, regionally and seasonally.

Whatever the nature of the krill-copepod interaction, a negative association between these major taxa must have a profound effect on ecosystem functioning. In this respect, our findings parallel those further south near the Antarctic Peninsula, where fluctuating 'krill years' and 'salp years' have been observed, with implications for changing carbon flows in a warming climate (Huntley et al. 1989, Siegel \& Loeb 1995, Loeb et al, 1997). Further north, copepods replace salps as a major group, but, likewise, shifts in dominance between krill and copepods must severely affect both. the food web and efficiency of faecal carbon export (von Bodungen 1986, Smetacek et al. 1990, Fortier et al. 1994). Diatom - krill - higher predator food chains are short, with efficient energy transfer to large higher predators. Copepod domination would mean longer, less efficient food chains and, due to the slower sinking rates of their faecal pellets, slower biogeochemical removal of carbon from the surface layer.

South Georgia supports fisheries for squid, krill and fish (Everson \& Goss 1991) as well as large populations of vertebrate predators. Managing this requires an understanding of how the food web works in order to 
predict how it will respond to change (Everson 1984, Whitehouse et al. 1996a). A decadal scale regional warming of the Antarctic Peninsula region was suggested to have coincided with a decline in krill abundance (Loeb et al. 1997). Copepods tend to be more abundant in warmer, northern regions of Antarctica (Foxton 1956, Hopkins 1971, Ward et al. 1997, Atkinson 1998), and South Georgia is near the northern limit of krill distribution. We speculate that a decline in krill here would release a major control on copepod abundance, allowing them to increase in response.

Acknowledgements. We thank the officers and crew and scientists aboard RRS 'John Biscoe' and 'James Clark Ross' who undertook the sampling, and M. Pilcher, J. M. Peck and R. S. Shreeve, who helped with zooplankton analysis. The manuscript was much improved by the comments from Drs J. Priddle, A. Hirst, M. A. Brandon and Prof. A. Clarke and an anonymous referee. A. W. A. Murray provided advice on statistics.

\section{LITERATURE CITED}

Antezana T, Ray K (1984) Active feeding of Euphausia superba in a swarm north of Elephant Island. J Crustac Biol 4(Spec No. 1):142-155

Atkinson A (1995) Omnivory and feeding selectivity in five copepod species during spring in the Bellingshausen Sea, Antarctica. ICES J Mar Sci 52:385-396

Atkinson A (1998) Life cycle strategies of Antarctic copepods J Mar Syst 15:289-311

Atkinson A, Peck JM (1990) The distribution of zooplankton in relation to the South Georgia shelf in summer and winter In: Kerry KR, Hempel G [eds\} Antarctic ecosystems. Ecological change and conservation. Springer-Verlag, Berlin, p 159-165

Atkinson A, Snyder R (1997) Krill-copepod interactions at South Georgia, Antarctica, I. Omnivory by Euphausia superba. Mar Ecol Prog Ser 160:63-76

Atkinson A, Ward P, Peck JM, Murray AWA (1990) Mesoscale distribution of zooplankton around South Georgia. DeepSea Res 37:1213-1227

Atkinson A, Ward P, Williams R, Poulet SA (1992) Feeding rates and diel vertical migration of copepods near South Georgia: comparison of shelf and oceanic sites. Mar Biol $114: 49-56$

Atkinson A, Shreeve RS, Pakhomov EA, Priddle J, Blight SP, Ward P (1996) Zooplankton response to a phytoplankton bloom near South Georgiâ, Antarctica. Mar Ecol Prog Ser 144:195-210

Atkinson A, Schnack-Schiel SB, Ward P, Marin V (1997) Regional differences in the life cycle of Calanoides acutus (Copepoda: Calanoida) within the Atlantic sector of the Southern Ocean. Mar Ecol Prog Ser 150:99-111

Bathmann UV, Makarov RR, Spiridonov VA, Rohardt G (1993) Winter distribution and overwintering strategies of the Antarctic copepod species Calanoides acutus, Rhincalanus gigas and Calanus propinquus (Crustacea, Calanoida) in the Weddell Sea. Polar Biol 13:333-346

Bollens SM. Stearns DE (1992) Predator-induced changes in the diel feeding cycle of a planktonic copepod. J Exp Mar Biol Ecol 156:179-186

Boyd IL, Croxall JP, Lunn NJ, Reid K (1995) Population demo- graphy of Antarctic fur seals: the costs of reproduction and implications for life histories. J Anim Ecol 64:505-518

Brierley AS, Watkins JL (1996) Acoustic targets at South Georgia and the South Orkney islands during a season of krill scarcity. Mar Ecol Prog Ser 138:51-61

Brierley AS, Watkins JL, Murray AWA (1997) Interannual variability in krill abundance at South Georgia. Mar Ecol Prog Ser 150:87-98

Brierley AS, Watkins JL, Goss C (1998) Krill biomass estimates for South Georgia, December/January 1996/1997. In: CCAMLR scientific abstracts. CCAMLR, Hobart, p 20 CCAMLR (1996) Statistical bulletin, Vol 8. CCAMLR, Hobart

Croxall JP, Ruthery $P$ (1995) Population change in gentoo

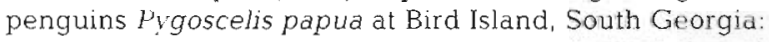
potential roles for adult survival, recruitment and deferred breeding. In: Dann P, Norman I, Reilly P (eds) The penguins. Surrey Beatty \& Sons Pty Ltd, Chipping Norton, NSW, p 26-38

Dawidowic P, Pijanowska J, Ciechomski K (1990) Vertical migration of Chaoborus larvae is induced by the presence of fish. Limnol Oceanogr 35:1631-1637

Everson I. (1984) Marine interactions. In: Laws RM (ed) Antarctic ecology, Vol 2. Academic Press Inc, London, p 783-819

Everson I, Bone DG (1986) Effectiveness of the RMT-8 system for sampling krill (Euphausia superba) swarms. Polar Bia] 6:83-90

Everson I, Goss C (1991) Krill fishing activity in the southwest Atlantic. Antarct Sci 3:351-358

Fortier L, Le Fevre J, Legendre L (1994) Export of biogenic carbon to fish and to the deep ocean: the role of large planktonic macrophages. J Plankton Res 16:809-839

Foxton P (1956) The distribution of the standing crop af zooplankton in the Southern Ocean. Discovery Rep 28: 191-236

Froneman PW, Pakhomov EA, Perissinotto R, McQuaid CD (1996) Role of microplankton in the diet and daily ration of Antarctic zooplankton species during austral summer. Mar Ecol Prog Ser 143:15-23

Frost BW, Bollens SM (1992) Variability of diel vertical migration in the marine planktonic copepod Pseudocalanus newmani in relation to its predators. Can J Fish Aquat Sci 49:1137-1141

Hamner WM, Hamner PP, Strand SW, Gilmer RW (1983) Behavior of Antarctic krill, Euphausia superba: chemoreception, feeding, schooling and molting. Science 220: $433-435$

Hardy AC (1936) Observations on the uneven distribution of oceanic plankton. Discovery Rep 11:511-538

Hardy AC, Gunther ER (1935) The plankton of the South Georgia whaling grounds and adjacent waters, 1926-1927. Discovery Rep 11:1-456

Hopkins TL (1971) Zooplankton standing crop in the Pacific sector of the Antarctic. Antarct Res Ser 17:347-362

Hopkins TL (1985) Food web of an Antarctic midwater ecosystem. Mar Biol 89:197-212

Hopkins TL, Torres JJ (1989) Midwater food web in the vicinity of a marginal ice zone in the western Weddell Sea. Deep-Sea Res 36:543-560

Hopkins TL, Ainloy DG, Torres JJ, Lancraft TM (1993a) Trophic structure in open waters of the marginal ice zone in the Scotia-Weddell confluence region during spring (1983). Polar Biol 13:389-397

Hopkins TL, Lancraft TM, Torres JJ, Donnelly J (1993b) Community structure and trophic ecology of zooplankton in the Scotia Sea marginal ice zone in winter (1988). Deep-Sea Res 40.81-105 
Hosie GW (1994) The macroplankton communities in the Prydz Bay region, Antarctica. In: El-Sayed SZ (ed) Southern Ocean ecology: the BIOMASS perspective. Cambridge University Press, Cambridge, p 93-123

Hosie GW, Cochran TG (1994) Mesoscale distribution patterns of macrozooplankton communities in Prydz Bay, Antarctica - January to February 1991. Mar Ecol Prog Ser $106: 21-39$

Huntley ME, Sykes PF, Marin V (1989) Biometry and trophodynamics of Salpa thompsoni Foxton (Tunicata: Thaliacea) near the Antarctic Peninsula in austral summer, 1983-1984. Polar Biol 10:59-70

Huntley ME, Nordhausen W, Lopez MDG (1994) Elemental composition, metabolic activity and growth of Antarctic krill Euphausia superba during winter. Mar Ecol Prog Ser $107: 23-40$

Kawamura A (1986) Has marine Antarctic ecosystem changed? - A tentative comparison of present and past macrozooplankton abundances. In: Hoshai $T$, Nemoto $T$ (eds) Proceedings of the Seventh Symposium on Polar Biology, Mem Natl Inst Polar Res 40:197-211

Kopczynskd EE (1992) Dominance of microflagellates over diatoms in the Antarctic areas of deep vertical mixing and krill concentrations. J Plankton Res 1.4:1031-1054

Loeb V, Siegel V, Holm-Hansen O, Hewitt R, Fraser W, Trivelpiece W. Trivelpiece $S$ (1997) Effects of sea ice extent and krill or salp dominance on the Antarctic food web. Nature 387:897-900

Longhurst AR, Williams R (1976) Improved filtration systems for multiple-serial plankton samplers and their deployment. Deep-Sea Res 23:1067-1073

Lopez MDG, Huntley ME, Lovette JT (1993) Calanoides acutus in Gerlache Strait, Antarctica, I. Distribution of late copepodite stages and reproduction during spring. Mar Ecol Prog Ser 100:153-165

Mackintosh NA (1934) Distribution of the macroplankton in the Atlantic sector of the Antarctic. Discovery Rep 9:65-160

Mackintosh NA (1973) Distribution of post larval krill in the Antarctic. Discovery Rep 36:95-156

Madureira LSP, Everson I, Murphy EJ (1993a) Interpretation of acoustic data at two frequencies to determine between Antarctic krill (Euphausia superba Dana) and other scatterers. J Plankton Res 15:787-802

Madureira LSP, Ward P, Atkinson A (1993b) Differences in backscattering strength determined at 120 and $38 \mathrm{kHz}$ for three species of Antarctic macroplankton. Mar Ecol Prog Ser $93: 17-24$

Makarov RR, Serebryakova MV, Solyankin YeV (1984) Phytoplankton drift transport and distribution in the vicinity of South Georgia island. Oceanology 24:110-115

Marn V (1987) The oceanographic structure of the eastern Weddell Sea: Part VI-distribution of copepod species in relation to hydrography in 1981. Deep-Sea Res 34: $105-121$

Marr J (1962) The natural history and geography of the Antarctic krill Euphausia superba Dana. Discovery Rep 32:33-464

McClatchie S (1985) Feeding behaviour of Meganyctiphanes norvegica (M. Sars) (Crustacea: Euphausiacea). J Exp Mar Biol Ecol 86:271-284

Miller DGM, Hampton I (1.989) Biology and ecology of the Antarctic krill (Euphausia superba Dana): a review. BIOMASS series, Vol 9, Cambridge

Morris DJ, Watkins JL, Ricketts C, Bucholz F, Priddle J (1988) An assessment of the merit of Jength and weight measurements of Antarctic krill Euphausia superba. Br Antarcl Surv Bull 79:27-50
Murphy E, Everson I, Murray A (1991) Analyses of acoustic line-transect data from the waters around South Georgia: estimation of krill (Euphausia superba Dana)-biomass In: Selected scientific papers 1991 (SC-CAMLR-SSP/8) CCAMLR, Hobart, p 225-243

Nishino Y, Kawamura A (1994) Winter gut contents of Antarctic krill (Euphausia superba Dana) collected in the South Georgia area. Proc NIPR Symp Polar Biol 7:83-90

Nordhausen W, Huntley M (1992) RACER: carnivory by Euphausia superba during the antarctic winter Antarct J US 27:181-183

Øresland V (1990) Feeding and predation impact of the chaetognath Eukrohnia hamata in Gerlache Strait, Antarctic Peninsula. Mar Ecol Prog Ser 63:201-209

Pakhomov EA, Perissinotto R (1996) Trophodynamics of the hyperiid amphipod Themisto gaudichaudii in the South Georgia region during late austral summer. Mar Ecol Prog Ser 134:91-100

Pakhomov EA, Perissinotto $\mathrm{R}$, Froneman PW, Miller DGM (1997a) Energetics and feeding dynamics of Euphausia superba in the South Georgia region during the summer of 1994. J Plankton Res 19:399-423

Pakhomov EA, Verhaye HM, Atkinson A, Laubscher RK, Taunton-Clarke J (1997b) Structure and grazing impact of the mesozooplankton community during late summer 1994 near South Georgia, Antarctica. Polar Biol 18: $180-192$

Pavlov VYa (1969) The feeding of krill and some features of its behaviour. Trudy Vses Nauchno-Issled Ryb Khoz Okeanogr 66:207-222 (Ministry of Agriculture, Food and Fisheries, UK, Translation No. NS 94)

Perissinotto R, Pakhomov EA, McQuaid CD, Froneman PW (1997) In situ grazing rates and daily ration of Antarctic krill Euphausia superba feeding on phytoplankton at the Antarctic Polar Front and the Marginal Ice Zone. Mar Ecol Prog Ser 160:77-91

Piatkowski U (1989) Macroplankton communities in Antarctic surface waters: spatial changes related to hydrography. Mar Ecol Prog Ser 55:251-259

Pommeranz T, Hermann C, Kuhn C (1983) Mouth angles of the Rectangular Midwater Trawl (RMT 1+8) during paying out and hauling. Meeresforschung 29:267-274

Pond D, Priddle J, Sargent J, Watkins JL (1993) Lipid composition of Antarctic microplankton in relation to the nutrition of krill. In: Heywood RB (ed) University research in Antarctica 1989-92. Proceedings of the British Antarctic Survey Special Topic Award Scheme Round 2 Symposium. British Aniarctic Survey, Cambridge, p 133-139

Price HJ (1989) Swimming behaviour of krill in response to algal patches. Limnol Oceanogr 34:649-659

Price HJ, Boyd KR, Boyd CM (1988) Omnivorous feeding behavior of the Antarctic krill (Euphausia superba). Mar Biol 97:67-77

Priddle J, Heywood RB, Theriot E (1986) Some environmental factors influencing phytoplankton in the Southern Ocean around South Georgia. Polar Biol 5:65-79

Priddle J, Whitehouse MJ, Atkinson A, Brierley AS, Murphy EJ (1997) Diurnal changes in near-surface ammonium concentration - interplay between zooplankton and phytoplankton. J Plankton Res 19:1305-1330

Quetin LB, Ross RM (1991) Behavioral and physiological characteristics of the Antarctic krill, Euphausia superba. Am Zool 31:49-63

Roe HSJ, Shale DM (1979) A new Multiple Rectangular Midwater Trawl (RMT $1+8$ ) and some modifications to the Institute of Oceanographic Science's RMT 1+8. Mar Biol 50:283-288 
Roe HSJ, Baker ADeC, Carson RM, Wild R, Shale DM (1980) Behaviour of the Institute of Oceanographic Science's Rectangular Midwater Trawl: theoretical aspects and experimental observations. Mar Biol 56:247-259

Rose GA, Leggett WC (1990) The importance of scale to predator-prey spatial correlations: an example of Atlantic fishes. Ecology 71:33-43

Schnack SB (1985) Feeding by Euphausia superba and copepod species in response to varying concentrations of phytoplankton. In: Siegfried WR, Condy PR, Laws RM (eds) Antarctic nutrient cycles and food webs. SpringerVerlag, Berlin, p 311-323

Schnack-Schiel SB, Hagen W (1995) Life cycle strategies of Calanoides acutus, Calanus propinquus, and Metridia gerlachei (Copepoda: Calanoida) in the eastern Weddell Sea, Antarctica. ICES J Mar Sci 52:541-548

Shulenberger E, Wormuth JH, Loeb VJ (1984) A large swarm of Euphausia superba: overview of patch structure and. composition. J Crustac Biol 4 (Spec No. 1):75-95

Siegel V, Loeb V (1995) Recruitment of Antarctic krill Euphausia superba and possible causes for its variability. Mar Ecol Prog Ser 123:45-56

Siegel V, Piatkowski U (1990) Variability in the macrozooplankton community off the Antarctic Peninsula. Polar Biol 10:373-386

Smetacek V, Scharek R, Nöthig EM (1990) Seasonal and regional variation in the pelagial and its relationship to the life history of krill. In: Kerry KR, Hempel G (eds) Antarctic ecosystems. Ecological change and conservation. Springer-Verlag, Berlin, p 103-114

Theriot E. Fryxell G (1985) Multivariate statistical analysis of net diatom species distributions in the southwest Atlantic and Indian Ocean. Polar Biol 5:23-30

Trathan PN, Brandon MA, Murphy EJ (1997) Characterisation of the Antarctic Polar Front Zone to the north of South Georgia in summer 1994. J Geophys Res 102:10483-10497

Trathan PN, Everson I, Murphy EJ, Parkes G (1998) Analysis

Editorial responsibility: Otto Kinne (Editor), Oldendorf/Luhe, Germany of haul data from the South Georgia fishery. CCAMLR Sci $5: 9-30$

Verity PG, Smetacek V (1996) Orgañism life cycles, predation, and the structure of pelagic marine ecosystems. Mar Ecol Prog Ser 130:277-293

von Bodungen B (1986) Phytoplankton growth and krill grazing during spring in the Bransfield Strait, Antarcticaimplications from sediment trap collections. Polar Biol 6: $153-160$

Vuorinen I, Hänninen J, Bonsdorff E, Boorman B, Angel MV (1997) Temporal and spatial variation of dominant pelagic Copepoda (Crustacea) in the Weddell Sea (Southern Ocean), 1929 to 1993. Polar Biol 18:280-291

Ward P, Atkinson A, Murray AWA, Wood AG, Williams R, Poulet SA (1995) The summer zooplankton community at South Georgia: biomass, vertical migration and grazing Polar Biol 15:195-208

Ward P, Shreeve RS, Cripps GC, Trathan PN (1996) Mesoscale distribution and population dynamics of Rhincalanus gigas and Calanus simillimus in the Antarctic open ocean and Polar Frontal Zone during summer. Mar Ecol Prog Ser 140:21-32

Ward P, Atkinson A, Schnack-Schiel SB, Murray AWA (1997) Regional variation in the life cycle of Rhincalanus gigas (Copepoda: Calanoida) in the Atlantic Sector of the Southern Ocean-re-examination of existing data (1928-1993). Mar Ecol Prog Ser 157:261-275

Whitehouse MJ, Priddle J, Symon C (1996a) Seasonal and annual change in seawater temperature, salinity, nutrient and chlorophyll a distributions around South Georgia, South Atlantic. Deep-Sea Res 43:425-443

Whitehouse MJ, Priddle J, Trathan PN, Brandon MA (1996b) Substantial open-ocean phytoplankton blooms to the north of South Georgia, South Atlantic, during summer 1994. Mar Ecol Prog Ser 140:187-197

Zar JH (1984) Biostatistical analysis. Prentice Hall International (UK) Ltd, London

Submitted: January 7, 1998; Accepted: September 24, 1998

Proofs received from author(s): December 17, 1998 